\title{
T Cell Recognition of Autoantigens in Human Type 1 Diabetes: Clinical Perspectives
}

\author{
Roberto Mallone, ${ }^{1,2,3}$ Vedran Brezar, ${ }^{1,2}$ and Christian Boitard ${ }^{1,2,3}$ \\ ${ }^{1}$ INSERM, U986, Hôpital St Vincent de Paul, 82 avenue Denfert Rochereau, 75014 Paris, France \\ ${ }^{2}$ Université Paris Descartes, 75005 Paris, France \\ ${ }^{3}$ Hôpital Cochin-Hôtel Dieu, Assistance Publique des Hôpitaux de Paris, 75679 Paris, France
}

Correspondence should be addressed to Christian Boitard, christian.boitard@htd.aphp.fr

Received 10 February 2011; Accepted 18 March 2011

Academic Editor: Vincent Geenen

Copyright (C) 2011 Roberto Mallone et al. This is an open access article distributed under the Creative Commons Attribution License, which permits unrestricted use, distribution, and reproduction in any medium, provided the original work is properly cited.

Type 1 diabetes (T1D) is an autoimmune disease driven by the activation of lymphocytes against pancreatic $\beta$-cells. Among $\beta$ cell autoantigens, preproinsulin has been ascribed a key role in the T1D process. The successive steps that control the activation of autoreactive lymphocytes have been extensively studied in animal models of T1D, but remains ill defined in man. In man, T lymphocytes, especially $\mathrm{CD} 8{ }^{+} \mathrm{T}$ cells, are predominant within insulitis. Developing T-cell assays in diabetes autoimmunity is, thus, a major challenge. It is expected to help defining autoantigens and epitopes that drive the disease process, to pinpoint key functional features of epitope-specific T lymphocytes along the natural history of diabetes and to pave the way towards therapeutic strategies to induce immune tolerance to $\beta$-cells. New T-cell technologies will allow defining autoreactive T-cell differentiation programs and characterizing autoimmune responses in comparison with physiologically appropriate immune responses. This may prove instrumental in the discovery of immune correlates of efficacy in clinical trials.

\section{Introduction}

Type 1 diabetes (T1D) is an autoimmune disease driven by the activation of lymphocytes against pancreatic $\beta$-cells. While the successive steps that control the activation of autoreactive lymphocytes have been extensively studied in animal models, the disease process remains ill defined in the human [1]. However, the predominant role of T lymphocytes is characteristic of both mouse and human T1D. In the mouse, T1D is transferred into naive recipients by $\mathrm{T}$ cells, is prevented by antibodies that target $\mathrm{T}$ lymphocyte activation, and fails to develop when key genes in $\mathrm{T}$ lymphocyte differentiation or activation are non functional [2]. T1D is a highly multigenic disease both in the mouse [3] and in the human [4]. In man, $\mathrm{T}$ lymphocytes, especially $\mathrm{CD} 8^{+} \mathrm{T}$ cells, are predominant within insulitis in most [5-11], although not all [12], observations. Occurrence of T1D in a patient deprived of $\mathrm{B}$ lymphocytes further underscores the role of $\mathrm{T}$ lymphocytes [13].
Remarkable features in human T1D are the long preclinical phase that precedes the development of full-blown hyperglycemia [14] and the high recurrence level of autoimmunity in long-standing patients who have been treated with exogenous insulin for years [15]. The first detection of autoantibodies can occur at any time during life. However, it peaks at one to three years of age in a large subset of children who develop early T1D. A second incidence peak is seen around puberty and show more heterogeneous autoantibody profiles than in early forms of T1D [14]. Rapid diabetes recurrence is seen in T1D recipients of an isograft from a discordant, nondiabetic twin and is accompanied by an almost exclusive $\mathrm{CD}^{+}$T-cell islet infiltration [15]. It, thus, seems that $\beta$-cell-specific $\mathrm{T}$ lymphocytes maintain immune memory for years after T1D onset. However, differentiation patterns of autoreactive T lymphocytes, once diabetes diagnosed, remain largely unknown.

Among $\beta$-cell autoantigens (Table 1), proinsulin has been ascribed a key role in the T1D process $[1,16]$. In the NOD 
TABle 1: Autoantigens defined as recognized by T cells in human T1D. Listing has been limited to autoantigens for which evidence of recognition has been obtained in the human or, if only in the mouse, data are expected in the human.

\begin{tabular}{|c|c|c|c|c|c|c|}
\hline \multirow{2}{*}{ autoantigen } & \multirow{2}{*}{ expression } & \multirow{2}{*}{ Subcellular location } & \multirow{2}{*}{ Involvement in the NOD mouse } & \multicolumn{3}{|c|}{ Human T1D } \\
\hline & & & & autoantibodies & $\mathrm{CD}^{+} \mathrm{T}$ cells & $\mathrm{CD}^{+} \mathrm{T}$ cells \\
\hline Insulin & $\beta$-cell, thymus & secretory granule & + & + & + & + \\
\hline *GAD 65 & neuroendocrine & $\begin{array}{l}\text { synaptic-like } \\
\text { microvesicles }\end{array}$ & + & + & + & + \\
\hline GAD 67 & neuroendocrine & cytosol & + & + & + & + \\
\hline IA-2 (ICA512) & neuroendocrine & secretory granule & & + & + & + \\
\hline IA- $2 \beta /$ phogrin & neuroendocrine & secretory granule & & + & + & + \\
\hline IGRP & $\beta$-cell & $\begin{array}{c}\text { endoplasmic } \\
\text { reticulum }\end{array}$ & + & $?$ & + & + \\
\hline Chromogranin & neuroendocrine & Secretory granule & + & $?$ & $?$ & $?$ \\
\hline ZnT8 & $\beta$-cell & secretory granule & $?$ & + & $?$ & $?$ \\
\hline $\begin{array}{l}\text { HSP-60 } \\
\text { HSP-70 }\end{array}$ & ubiquitous & mitochondria & + & + & + & $?$ \\
\hline Glima-38 & & secretory granule & $?$ & + & $?$ & $?$ \\
\hline Amylin/IAPP & & secretory granule & $?$ & $?$ & $?$ & + \\
\hline CD38 & ubiquitous & $?$ & $?$ & \pm & $?$ & $?$ \\
\hline
\end{tabular}

GAD: glutamate decarboxylase; IA-2: islet antigen 2; ZnT8; HSP: heat shock protein; IAPP; IGRP; ICA: islet cell antibody.

?: no positive results reported.

mouse, injection of insulin-specific T-cell clones accelerates diabetes and protection is obtained by injecting insulin in incomplete Freund's adjuvant in prediabetic mice [2, 17]. Altered diabetes development in proinsulin $1^{-/-}$or $2^{-/-}$ NOD mice makes a strong case for the primary role of insulin in this model [18-20]. By contrast, deficient expression of glutamate decarboxylase (GAD) or islet antigen 2 (IA-2) has no striking effect on diabetes development in this model $[21,22]$. Antigen spreading may thus explain the activation of $T$ cells against a long list of autoantigens once the autoimmune process on. $\mathrm{T}$ cell clones that are specific for GAD, chromogranin and islet-glucose-6-phosphatase catalytic subunit-related protein (IGRP) are indeed detected and transfer diabetes into naive NOD recipients [23-26]. In man, insulin and proinsulin are common targets of autoantibodies and $\mathrm{T}$ cells in (pre)diabetic individuals [2737]. Insulin autoantibodies (IAA) are the first to be detected in children at risk for T1D and carry a high positive predictive value for diabetes in siblings of T1D patients [14, 28]. However, autoantibodies and $\mathrm{T}$ cells have been detected against autoantigens other than insulin in the human [38].

The immune image of the $\beta$-cell is that of native components of the $\beta$-cell membrane in their three-dimensional conformation, as seen by B lymphocytes, and, more importantly, of fragments of intracellular $\beta$-cell proteins in the form of 8-11 mer peptides loaded onto class I major histocompatibility complex (MHC) molecules, as seen on the $\beta$-cell surface by $\mathrm{CD}^{+} \mathrm{T}$ lymphocytes. In addition, professional antigen-presenting cells (APCs) present fragments of autoantigens that are phagocytosed following the release of subcellular $\beta$-cell particles or $\beta$-cell debris in the extracellular milieu and loaded onto MHC class I and class II molecules. Given the key role of $\mathrm{T}$ lymphocytes in the T1D disease process, the cartography of autoantigen-derived peptides that are presented to class I-restricted $\mathrm{CD} 8^{+} \mathrm{T}$ cells and class II-restricted $\mathrm{CD} 4^{+} \mathrm{T}$ cells, although still incomplete, will be the main focus of this paper.

\section{T Cell Recognition of Insulin}

Both direct evidence in the mouse and indirect evidence in the human point at insulin as a key autoantigen in T1D autoimmunity. The search for $\mathrm{T}$ cell recognition of insulin and the characterization of insulin epitopes recognized by $\mathrm{T}$ lymphocytes along disease development is thus a major challenge.

2.1. $C D 4^{+} T$ Cell Responses to Proinsulin. The study of $\mathrm{T}$ cell responses to $\beta$-cell autoantigens have long been limited to MHC class II-restricted responses but have faced major methodological caveats, precluding translation into routine laboratory procedures. $\mathrm{CD} 4^{+} \mathrm{T}$ cell responses to exogenous insulin have first been studied [39]. They have been shown to be exacerbated in response to inhaled insulin in T1D patients and in patients treated with insulin analogs, in particular insulin detemir. They are beyond the scope of this paper that will focus on $\mathrm{T}$ cell responses to insulin as part of the autoimmune response to $\beta$-cells. Autoimmunity to insulin seen in the rare insulin autoimmune syndrome in patients with Grave's disease will not be detailed either [39]. Following studies associating the detection of antibodies to exogenous insulin to HLA-DR4, HLA-DR4-restricted T cell responses have first been prioritized. The characterization of the high susceptibility DQ8 molecule led to the characterization of DQ8-restricted responses in addition to DR4restricted responses. 
Proliferative $\mathrm{T}$ cell responses have been reported in the human against both insulin and proinsulin, especially in recent-onset T1D patients and prediabetic individuals [29$31,35]$ although also in nondiabetic subjects in some reports $[36,40]$. Despite treatment with insulin, long-standing T1D patients were often found low responders [30,31], as also observed in case of $\mathrm{CD}^{+} \mathrm{T}$ cells [32]. An inverse correlation has been observed between the presence of anti-insulin autoantibodies and $\mathrm{T}$ cell responses to proinsulin $[29,30]$, although not to insulin [40] and not in all studies [40, 41]. Some patients showed a response to proinsulin, although not to insulin, indicating that C-peptide residues were among the epitopes recognized [30]. Responses to insulin have been observed in $25 \%$ of T1D patients and $10 \%$ of siblings in a model in which proliferative responses were increased in siblings of T1D patients, although not T1D patients themselves, by addition of anti-DQ antibodies, implying the presence of primed suppressive HLA-DQ-restricted T cell responses to insulin in siblings [42].

Epitopes of proinsulin have been characterized in the human [43] (Table 2). Using class II knockout mice that were transgenic for the DQ8 diabetes susceptibility class II allele, two immunodominant preproinsulin regions have been defined, spanning residues 1-24 and 44-63, respectively. Immunodominant regions, that is, $14-33$ and $74-93$, were different in diabetes resistant transgenic mice that express the diabetes resistant DQ6 allele [44]. Epitopes spanning the C-peptide and A-chain junction have also been reported as immunodominant in DR1*0401 transgenic mice [45]. Using a preproinsulin peptide library, immunodominant epitopes located within the $\mathrm{C}$ peptide $\left(\mathrm{C}_{13-29}\right)$ and $\mathrm{B}$ chain $\left(\mathrm{B}_{11-27}\right)$ were preferentially recognized by $\mathrm{CD} 4^{+} \mathrm{T}$ cells from autoantibody positive individuals at high risk for T1D development whereas $\mathrm{CD} 4^{+} \mathrm{T}$ cells from insulin-treated T1D patients were responsive to native insulin and insulin $\mathrm{B}$ chain $\left(B_{1-16}\right)$. Unexpectedly, an IL-4 and IL-10 response was predominant in both the naive $\mathrm{CD} 45 \mathrm{~A}$ and memory CD45RO T cell compartments [36].

The role of the insulin $\mathrm{B}$ chain peptide $\mathrm{B}_{9-23}$ in the NOD mouse led to test whether this peptide could also be recognized in human T1D. Importantly, the three dimensional structure of the DQ8 molecule complexed with insulin peptide $\mathrm{B}_{9-23}$ has been determined [46]. Short-term $\mathrm{T}$ cell lines obtained following a 7-10 day incubation of peripheral blood mononuclear cells (PMBCs) from 10/12 recent-onset T1D patients, while not from controls, have been shown highly proliferative to $\mathrm{B}_{9-23}$. Insulin $\mathrm{B}_{9-23}$ specific $\mathrm{T}$ cell lines were restricted by HLA-DQ8 which shows striking structural similarities with the NOD mouse $\mathrm{IA}^{\mathrm{g} 7}$ class II molecule. Substantial numbers of interferon $\gamma$-producing cells were detected in most recent-onset T1D patients and prediabetic subjects using an ELISpot assay [34]. However, the extent to which a $B_{9-23}$ proliferative assay can apply to routine evaluation in T1D remains elusive. Presentation of peptide $\mathrm{B}_{9-23}$ was confirmed in class II knock out mice that were made transgenic for the human DQ8 allele [47]. The characterization of peptides eluted from HLA-DR4 class II molecules further allowed defining naturally processed proinsulin epitopes that clustered in the $\mathrm{C}$ peptide and $\mathrm{C}$ peptide-A chain junction. Significant responses were observed against $\mathrm{C}_{13-32}, \mathrm{C}_{19}-\mathrm{A}_{3}$ and $\mathrm{C}_{22}$ $\mathrm{A}_{5}$. A positive interferon $\gamma$ response to proinsulin peptides was detected in $56 \%$ of 25 T1D patients and in none of 14 control subjects. By contrast, an IL-10 response to proinsulin peptides was detected in one out of four control subjects and T1D patients. An inverse correlation was observed between the interferon $\gamma$ and the IL-10 response to IA-2 and proinsulin peptides, although not to tetanus toxoid, in patients and control subjects. Type 1 diabetic patients who showed an IL-10 response were older at onset of diabetes than patients who showed an interferon $\gamma$ response [48].

In a different set of experiments, expansion of $\mathrm{T}$ cells from pancreatic draining lymph nodes of subjects with T1D and controls allowed characterizing $\mathrm{T}$ cell clones. While $\mathrm{T}$ cell clones from control individuals were highly polyclonal in light of heterogeneous $\mathrm{V} \beta \mathrm{T}$ cell receptor usage, around $50 \%$ of T cell clones from 2 of 3 T1D patients expressed identical $\mathrm{V} \beta$ chains, favoring an antigen-driven expansion of $\mathrm{T}$ cells. Half of clonally expanded clones from the 2 patients were specific for insulin $A_{1-15}$. Both patients were HLA-DR401 which is strongly associated with susceptibility to T1D, but also to insulin antibodies in insulin-treated patients. Both patients, however, were long-standing T1D subjects who had been treated with insulin for over than 10 years when lymph node were collected. No response to insulin in blood, spleen or pancreatic lymph nodes from a type 2 diabetic patient treated with insulin was observed. It is hypothesized that $\mathrm{T}$ cells residing in the pancreatic lymph nodes may persist in individuals in whom $\beta$ cells have been eliminated for years [49]. The use of a human DR4B1*0401-restricted CD4 ${ }^{+}$ $\mathrm{T}$ cell clone that was obtained from a prediabetic, insulin autoantibody-positive child further allowed showing that posttranslational modifications of insulin epitopes impacts on recognition by autoreactive $\mathrm{T}$ cells. The $\mathrm{T}$ cell clone was specific for $\mathrm{A}_{1-13}$ and proliferated to human islet insulin, indicating that the epitope was derived from native insulin. The authors failed to obtain $\mathrm{CD} 4^{+} \mathrm{T}$ cell clones specific for this epitope from two healthy donors. Recognition by the $A_{1-13}$-specific $T$ cell clone was dependent on the formation of a disulfide bond between adjacent cysteine residues $\mathrm{A}_{6}$ and $A_{7}$ which, however, did not alter peptide binding to HLA-DR4. The $A_{6}$ and $A_{7}$ cysteine residues were required for $\mathrm{T}$ cell recognition by this clone, while the $A_{11}$ cysteine residue was not. Recognition of $\mathrm{A}_{1-13}$ was dependent on the presence of oxidized residues that allowed formation of a disulfide bond between residues $\mathrm{A}_{6}$ and $\mathrm{A}_{7}$ [50]. These data strengthen previous evidence that the oxidation state of insulin-derived peptides plays a role in recognition by insulin $\mathrm{A}_{1-14}$-specific $\mathrm{T}$ cells. Murine $\mathrm{I}-\mathrm{A}^{\mathrm{b}}$ and $\mathrm{I}-\mathrm{A}^{\mathrm{d}}$ restricted polyclonal $\mathrm{T}$ cells and $\mathrm{T}$ cell clones that were specific for bovine $A_{1-14}$ were shown to require reduction of disulfide bonds for recognition [51]. Human DR1-restricted $\mathrm{T}$ cell lines derived from insulin-treated patients were shown to require intact disulfide bonds at $\mathrm{A}_{6}$ and $\mathrm{A}_{7}[52]$.

2.2. $C D 8^{+} T$ Cell Responses to Proinsulin. In human T1D, a number of proinsulin epitopes that are presented by MHC 
TABle 2: Class II-restricted* CD4 ${ }^{+}$T-cell epitopes on human preproinsulin.

\begin{tabular}{|c|c|c|c|c|}
\hline §Epitope preproinsulin & ${ }^{\S}$ Epitope Insulin nomenclature & MHC restriction & responders & references \\
\hline $\mathrm{PPI}_{1-24}$ & $\mathrm{~L}_{1-24}$ & DQ8 & Transgenic mice & {$[44]$} \\
\hline $\mathrm{PPI}_{11-26}$ & $\mathrm{~L}_{11}-\mathrm{B}_{2}$ & $\mathrm{DRB} 1 * 0401$ & Transgenic mice & {$[45]$} \\
\hline $\mathrm{PPI}_{14-33}$ & $\mathrm{~L}_{14}-\mathrm{B}_{9}$ & DQ6 & Transgenic mice & {$[44]$} \\
\hline $\mathrm{PPI}_{20-36}$ & $\mathrm{~L}_{20}-\mathrm{B}_{12}$ & $\mathrm{DRB}^{*} 0401$ & Transgenic mice & {$[45]$} \\
\hline $\mathrm{PPI}_{21-36}$ & $\mathrm{~L}_{21}-\mathrm{B}_{12}$ & DR4 & Transgenic mice & {$[36,45]$} \\
\hline $\mathrm{PPI}_{33-47}$ & $\mathrm{~B}_{9-23}$ & DQ8 & At risk/recent-onsetTransgenic mice & {$[35,47]$} \\
\hline $\mathrm{PPI}_{35-51}$ & $\mathrm{~B}_{11-27}$ & DR16 & At risk & {$[36]$} \\
\hline $\mathrm{PPI}_{44-63}$ & $\mathrm{~B}_{20}-\mathrm{C}_{7}$ & DQ8 & Transgenic mice & {$[44]$} \\
\hline $\mathrm{PPI}_{59-74}$ & $\mathrm{C}_{3}-\mathrm{C}_{18}$ & $\mathrm{DR}$ & Human T cell lines & {$[140]$} \\
\hline $\mathrm{PPI}_{73-90}$ & $\mathrm{C}_{17}-\mathrm{A}_{1}$ & DR4 & Transgenic mice & {$[45]$} \\
\hline $\mathrm{PPI}_{75-91}$ & $\mathrm{C}_{19}-\mathrm{A}_{3}$ & DR4 & T1D & {$[48]$} \\
\hline $\mathrm{PPI}_{78-94}$ & $\mathrm{C}_{22}-\mathrm{A}_{5}$ & DR4 & T1D & {$[48]$} \\
\hline $\mathrm{PPI}_{74-93}$ & $\mathrm{C}_{19}-\mathrm{A}_{4}$ & DQ6 & Transgenic mice & {$[44]$} \\
\hline $\mathrm{PPI}_{70-93}$ & $\mathrm{C}_{13}-\mathrm{A}_{6}$ & $\mathrm{DRB}^{*} 0401$ & Transgenic mice & {$[45]$} \\
\hline $\mathrm{PPI}_{85-101}$ & $\mathrm{C}_{29}-\mathrm{A}_{12}$ & $\mathrm{DRB} 1 * 0401$ & Transgenic mice & {$[45]$} \\
\hline $\mathrm{PPI}_{69-88}$ & $\mathrm{C}_{13-32}$ & DR4 & T1D & {$[48]$} \\
\hline $\mathrm{PPI}_{75-92}$ & $\mathrm{C}_{19}-\mathrm{A}_{3}$ & DR4 & T1D & {$[48]$} \\
\hline $\mathrm{PPI}_{78-94}$ & $\mathrm{C}_{22}-\mathrm{A}_{5}$ & DR4 & T1D & {$[48]$} \\
\hline $\mathrm{PPI}_{27-102}$ & $\mathrm{C}_{29}-\mathrm{A}_{12}$ & DR4 & Transgenic mice & {$[45]$} \\
\hline $\begin{array}{l}\mathrm{PPI}_{90-104} \\
\mathrm{PPI}_{90-102}\end{array}$ & $\mathrm{~A}_{1-15}, \mathrm{~A}_{1-13}$ & $\mathrm{DRB} 1^{*} 0401$ & $\begin{array}{c}\text { T cell clones } \\
\text { Long-standing T1D }\end{array}$ & {$[49,51]$} \\
\hline $\begin{array}{l}\text { The preproinsulin nomen } \\
\text { differences with cited refere } \\
\text { leader sequence: MALWMR } \\
\text { B chain: FVNQHLCGSHLV } \\
\text { C peptide: (RR)EAEDLQVC } \\
\text { A chain: GIVEQCCTSICSL } \\
\$ \S_{\text {Eppitopes for which class }} \\
\mathrm{L}_{13}-\mathrm{B}_{4}, \mathrm{~L}_{17}-\mathrm{B}_{8}, \mathrm{~B}_{1-16}, \mathrm{~B}_{6}-\mathrm{H} \\
\mathrm{B}_{10-25}, \mathrm{~B}_{25}-\mathrm{C}_{8},[140-142] .\end{array}$ & $\begin{array}{l}\text { ture here refers to the human prepro } \\
\text { es): } \\
\text { PLLALLALWGPDPAAA; } \\
\text { LLYLVCGERGFFYTPKT; } \\
\text { VELGGGPGASGLQPLALEGSLQ(RR } \\
\text { LENYCN. } \\
\text { restriting alleles have not been define } \\
\text {, }_{16-32}, B_{25}-C_{9}, \text { PPI }_{67-83}, C_{13-29}[3\end{array}$ & $\begin{array}{l}\text { lin sequence (errors } \\
\text { ) are excised during } \\
\mathrm{B}_{1}-\mathrm{B}_{17}, \mathrm{~B}_{11}-\mathrm{B}_{27}, \mathrm{~B}_{20}\end{array}$ & $\begin{array}{l}\text { some publications have been corrected her } \\
\text { alin processing; } \\
\text { ble: } \mathrm{PPI}_{1-16}\left(\mathrm{~L}_{1-16}\right), \mathrm{PPI}_{5-20}\left(\mathrm{~L}_{5-20}\right), \mathrm{PPI}_{9} \\
\mathrm{~B}_{24}-\mathrm{C}_{4}, \mathrm{~B}_{30}-\mathrm{C}_{14}, \mathrm{C}_{8}-\mathrm{C}_{24}, \mathrm{C}_{18}-\mathrm{A}_{1}, \mathrm{C}_{28}-\mathrm{A}_{1}\end{array}$ & $\begin{array}{l}\text { ich explains } \\
\text { L9-24), PPI, } \\
-\mathrm{A}_{21}[141] \text {; }\end{array}$ \\
\hline
\end{tabular}

class I alleles have been characterized (Table 3). In a first study using peptide library-mediated in vitro assembly of class I molecules, proinsulin peptides have been defined on the basis of their association with HLA-B8, A2, and B15. Several epitopes harbor anchor residues that were only weakly predicted or not predicted by common algorithms or that did not contain canonical allele-specific binding motifs [53]. Preproinsulin epitopes that carry C-terminal residues that are generated by proteasome digestion in vitro follow SYFPEITHI and BIMAS algorithm prediction and bind in vitro to purified class II allele have been further characterized [54-56]. In case of the common HLA-A*0201 allele, immunogenicity in class I knock out A2.1 transgenic mice has further been evidenced $[54,56]$. However, selftolerance to mouse proinsulin epitopes is expected to interfere with immunogenicity of human proinsulin peptides in these mice. CTL that could be maintained in vitro after restimulation were cytotoxic to A2.1 target cells, indicating that corresponding proinsulin epitopes were naturally processed by cells expressing proinsulin. Further studies characterized selected peptides within the proinsulin $\mathrm{B}-\mathrm{C}$ region for recognition by peripheral blood mononuclear cells from A1, A2, A3, A11, A24, B8, and B18 type 1 diabetic patients [55] and peptides located within the preproinsulin leader sequence $[56,57]$. T cells specific for leader sequence peptide ${ }_{15-24}$ were shown cytotoxic to human islets expressing HLA-A*0201, bringing further evidence that corresponding $\mathrm{T}$ cells may participate to $\beta$-cell destruction along the human disease process [57]. Leader sequence peptide ${ }_{14-23}$ has been shown distinct from peptide ${ }_{15-24}$ [56], but peptide ${ }_{15-24}$ has been eluted from HLA-A*0201 molecules [57]. A majority of T1D patients shows significant responses to at least one of the peptides covering the whole preproinsulin sequence, while no response is usually observed in control individuals, including type 2 diabetic patients who are treated with exogenous insulin. There is no correlation between the prevalence of responses to proinsulin peptides and the affinity levels of peptide binding to purified HLA class I molecules. In many patients, responses are observed to several peptides. However, the long preclinical phase that precedes clinical diabetes does not preclude that a more restricted set of peptides is recognized at initiation of the autoimmune process. More surprisingly, proinsulin peptides were recognized both in recent-onset and long-standing diabetic patients $[55,56]$. This may indicate that long-term memory class I-restricted $\mathrm{T}$ cells persist in the long term 
TABLE 3: CD8 ${ }^{+}$T-cell epitopes on human preproinsulin.

\begin{tabular}{|c|c|c|c|c|}
\hline Epitope preproinsulin & Epitope Insulin nomenclature & MHC restriction & responders & references \\
\hline $\mathrm{PPI}_{2-10}$ & $\mathrm{~L}_{2-10}$ & HLA-A*0201 & Recent-onset T1D & {$[96]$} \\
\hline $\mathrm{PPI}_{2-11}$ & $\mathrm{~L}_{2-11}$ & HLA-A*0201 & Recent-onset T1D & {$[56]$} \\
\hline $\mathrm{PPI}_{2-11}$ & $\mathrm{~L}_{2-11}$ & HLA-A24 & Recent-onset T1D & {$[56]$} \\
\hline $\mathrm{PPI}_{2-11}$ & $\mathrm{~L}_{2-11}$ & HLA-B8 & Recent-onset T1D & {$[56]$} \\
\hline $\mathrm{PPI}_{6-14} / \mathrm{PPI}_{6-16}$ & $\mathrm{~L}_{6-14} / \mathrm{L}_{6-16}$ & HLA-A*0201 & Recent-onset T1D & {$[56]$} \\
\hline $\mathrm{PPI}_{14-23}$ & $\mathrm{~L}_{14-23}$ & HLA-A*0201 & Recent-onset T1D & {$[56]$} \\
\hline $\mathrm{PPI}_{15-25}$ & $\mathrm{~L}_{14}-\mathrm{B}_{1}$ & HLA-A*0201 & Recent-onset T1D & {$[56]$} \\
\hline $\mathrm{PPI}_{15-24}$ & $\mathrm{~L}_{15}-\mathrm{L}_{24}$ & HLA-A*0201 & Recent-onset T1D & [57] \\
\hline $\mathrm{PPI}_{15-25}$ & $\mathrm{~L}_{14}-\mathrm{B}_{1}$ & HLA-A*0201 & Transgenic mice & {$[54]$} \\
\hline $\mathrm{PPI}_{23-42}$ & $\mathrm{~L}_{23-18}$ & HLA-A24 & Recent-onset T1D & [56] \\
\hline $\mathrm{PPI}_{34-42}$ & $\mathrm{~B}_{10-18}$ & HLA-A*0201 & $\begin{array}{l}\text { Recent-onset T1D } \\
\text { Islet graft rejection } \\
\text { Transgenic mice }\end{array}$ & {$[54,55,58$} \\
\hline $\mathrm{PPI}_{38-46}$ & $\mathrm{~B}_{14-22}$ & HLA-A3 & Recent-onset T1D & {$[55]$} \\
\hline $\mathrm{PPI}_{38-46}$ & $\mathrm{~B}_{14-22}$ & HLA-A11 & Recent-onset T1D & [55] \\
\hline $\mathrm{PPI}_{39-47}$ & $\mathrm{~B}_{15-23}$ & HLA-A24 & Recent-onset T1D & {$[141]$} \\
\hline $\mathrm{PPI}_{39-48}$ & $\mathrm{~B}_{15-24}$ & HLA-A24 & Recent-onset T1D & {$[55]$} \\
\hline $\mathrm{PPI}_{41-50}$ & $\mathrm{~B}_{17-26}$ & HLA-A1 & Recent-onset T1D & {$[55]$} \\
\hline $\mathrm{PPI}_{41-50}$ & $\mathrm{~B}_{17-26}$ & HLA-A3 & Recent-onset T1D & [55] \\
\hline $\mathrm{PPI}_{41-50}$ & $\mathrm{~B}_{17-26}$ & HLA-A11 & Recent-onset T1D & {$[55]$} \\
\hline $\mathrm{PPI}_{42-51}$ & $\mathrm{~B}_{18-27}$ & HLA-A1 & $\begin{array}{l}\text { Recent-onset T1D } \\
\text { Transgenic mice }\end{array}$ & {$[54,55]$} \\
\hline $\mathrm{PPI}_{42-51}$ & $\mathrm{~B}_{18-27}$ & HLA-A*0201 & Recent-onset T1D & {$[55]$} \\
\hline $\mathrm{PPI}_{42-51}$ & $\mathrm{~B}_{18-27}$ & HLA-B8 & Recent-onset T1D & {$[55]$} \\
\hline $\mathrm{PPI}_{42-51}$ & $\mathrm{~B}_{18-27}$ & HLA-B18 & Recent-onset T1D & {$[55]$} \\
\hline $\mathrm{PPI}_{44-51}$ & $\mathrm{~B}_{20-27}$ & HLA-A1 & Recent-onset T1D & {$[55]$} \\
\hline $\mathrm{PPI}_{44-51}$ & $\mathrm{~B}_{20-27}$ & HLA-B8 & Recent-onset T1D & [55] \\
\hline $\mathrm{PPI}_{45-53}$ & $\mathrm{~B}_{21-29}$ & HLA-A3 & Recent-onset T1D & {$[55]$} \\
\hline $\mathrm{PPI}_{49-57}$ & $\mathrm{~B}_{25}-\mathrm{C}_{1}$ & HLA-B8 & Recent-onset T1D & [55] \\
\hline $\mathrm{PPI}_{51-61}$ & $\mathrm{~B}_{27}-\mathrm{C}_{5}$ & HLA-B8 & Recent-onset T1D & [55] \\
\hline $\mathrm{PPI}_{76-84}$ & $\mathrm{C}_{20-28}$ & HLA-A*0201 & $\begin{array}{l}\text { Transgenic mice } \\
\text { Recent-onset T1D }\end{array}$ & {$[54,96]$} \\
\hline $\mathrm{PPI}_{83-89}$ & $\mathrm{C}_{27}-\mathrm{C}_{(34)}$ & HLA-A*0201 & Transgenic mice & {$[54]$} \\
\hline $\mathrm{PPI}_{85-94}$ & $\mathrm{C}_{29}-\mathrm{A}_{5}$ & HLA-A*0201 & $\begin{array}{l}\text { Transgenic mice } \\
\text { Recent-onset T1D }\end{array}$ & {$[54,96]$} \\
\hline $\mathrm{PPI}_{90-99}$ & $A_{1-10}$ & HLA-A*0201 & Transgenic mice & {$[54]$} \\
\hline $\mathrm{PPI}_{101-109}$ & $\mathrm{~A}_{12-20}$ & HLA-A*0201 & $\begin{array}{l}\text { Transgenic mice } \\
\text { Recent-onset T1D }\end{array}$ & {$[54,96]$} \\
\hline
\end{tabular}

range in patients who have been deprived of residual $\beta$ cells for years. Long term persistence of memory $\mathrm{CD}^{+} \mathrm{T}$ cells may explain the dramatic recurrence of T1D in recipients of hemigrafts from monozygotic, diabetes-discordant twins [15]. Reactivity to one of the B chain peptides identified, preproinsulin ${ }_{33-47} / \mathrm{B}_{10-18}$, was shown to elicit a $\mathrm{CD} 8^{+} \mathrm{T}$ cell response in long-standing T1D patients who undergo islet graft rejection using an ELISpot for granzyme, interferon $\gamma$ and IL-10 production and immunostaining with A2.1peptide tetramers [58]. In the NOD mouse in which no $\mathrm{T}$ cell activation is seen in mice deprived of $\beta$-cells at an early stage of the autoimmune process, full activation of $\mathrm{T}$ cells is seen in the absence of residual $\beta$-cells once the autoimmune process initiated [59]. The frequency of preproinsulin-specific $\mathrm{CD}^{+} \mathrm{T}$ cells has been estimated, using interferon $\gamma$ ELISpot assays, at a median frequency of $0.004 \%$ (range $0.0008-0.08 \%$ ) of PMBCs [32]. In this last study, they waned within 6 months after diabetes onset. However, persistence of $\mathrm{CD}^{+} \mathrm{T}$ cell responses have been observed in long-standing, insulin-treated T1D patients, in particular to B chain peptides, as opposed to leader sequence peptides $[55,56]$. The combination of high sensitivity flow 
cytometry detection and multiplex fluorescent reagents [60] is likely to allow high throughput $\mathrm{CD}^{+} \mathrm{T}$ cell analyses complemented by functional studies in a near future.

\section{T Cell Recognition of GAD, IA-2, and IGRP}

While insulin can be defined as a primary target of the autoimmune response to $\beta$-cells in the NOD mouse, direct evidence is lacking in the human. T cell recognition of autoantigens other than insulin has been defined in the human. The lack of routine human T-cell assays is due to intrinsic difficulties in measuring T-cell responses, in particular in case of $\mathrm{CD} 4^{+} \mathrm{T}$ cells [61]. Circulating antigen-specific $\mathrm{T}$ cells are present at a very low frequency. Although these cells are sometimes detectable ex vivo, their rarity challenges the sensitivity of technologies such as enzyme-linked immunospot (ELISpot) and flow cytometry. Peptides that bind to HLA class II molecules for presentation and recognition by T-cells have been more difficult to characterize in case of $\mathrm{CD}^{+}$than $\mathrm{CD}^{+} \mathrm{T}$ cells, due to looser binding constraints in case of class II than class I epitopes. Humanized mouse models expressing human class I or class II HLA molecules have largely been used to define class I-restricted and class II-restricted epitopes.

3.1. $C D 4^{+} T$ Cells. Following the discovery of insulin as an autoantigen in T1D, GAD was discovered as a second autoantigen based on homologies of antigen precipitates with the target of autoantibody in stiff man syndrome. IA2 was then discovered in 1994. Autoantibodies detected in recent-onset T1D patients recognize predominantly the cytoplasmic domain of IA-2, which shares $80 \%$ sequence homology with another tyrosine phosphatase, also known as phogrin $[62,63]$. Several approaches have been developed to define $\mathrm{CD}^{+} \mathrm{T}$ cells in T1D. An extensive description of epitopes recognized has been provided in a previous review [43]. Increased proliferation of $\mathrm{CD}^{+} \mathrm{T}$ cells has been reported in the presence of GAD extracted from pig or human brain and islets [64, 65], overlapping peptides covering the GAD65 and GAD67 sequences, in particular a region covering residues 473-555, while other regions were recognized by $\mathrm{T}$ cells from both T1D patients and controls [66], recombinant GAD65 and GAD67 [67-69] in up to two third of patients with recent-onset or subjects at risk for T1D. However, proliferative responses have also been observed in normal individuals. An inverse relation between the detection of anti-GAD autoantibodies and proliferative responses to GAD has been documented [69]. Proliferative responses to a GAD region located at positions $247-279$ has been correlated with responses to residues $32-47$ of the coxsackie P2-C viral sequence [70]. It is noteworthy that this region is located outside of the human GAD65 region $\left(\mathrm{GAD}_{473-543}\right)$ that was shown to be immunodominant in T1D patients [66]. T cell proliferative responses were also searched against selected GAD peptides, such as GAD65 $506-518$ which shows striking homology with proinsulin ${ }_{24-36}[33,71]$ or GAD65 $247-279$, a response that was correlated to $\mathrm{T}$ cell proliferative responses to coxsackie viral peptide $\mathrm{P} 2-\mathrm{C}_{32-47}$ [70]. DQ-restricted responses to recombinant GAD have further been defined in patients [42]. Several publications have since reported proliferative responses of $\mathrm{CD} 4^{+} \mathrm{T}$ cells from T1D patients or autoantibody-positive subjects at risk for T1D in the presence of IA-2 or IA-2 peptides $[40,72]$. Using IFN$\gamma /$ IL-4 double-color ELISPOT, IA-2-specific, interferon $\gamma$ secreting PMBCs were detected ex vivo in T1D patients while not in controls [73]. A dominant IA-2 $205-820$ epitope in these studies was shown to share $56 \%$ identity with a VP7 rotavirus protein [72]. However, difficulties to develop reliable assays in these pioneering studies have hampered further studies and may have explained variable outcomes, low reproducibility of data, difficult discrimination of responses in T1D patients and controls and failure to establish clinically relevant assays. Standardization of conditions of antigen presentation, restriction by class II HLA molecules and profiles of cytokines produced along these assays were usually unknown in these studies.

The use of transgenic mice expressing functional MHC class II molecules have been useful in helping to characterize GAD and IA-2 class II epitopes. The first class II transgenic mice to be developed carried a DRB1*0401 susceptibility allele. They led to identification of two peptides, selected among overlapping 20 mer peptides as binding to $\mathrm{DRB} 1 * 0401$, as immunogenic and naturally processed by DRB1*0401-expressing mouse spleen cells, GAD65 $274-286$ and GAD65 $115-127$ [74]. Another study in DR4-transgenic mice found that GAD65 $274-286$ and GAD65 $115-127$ and an additional peptide, GAD65 $551-565$, were immunodominant [75]. GAD65 $551-565$ was shown to be naturally processed by using a combination of chromatography and mass spectrometry of peptides bound by HLA-DR401 molecules [76]. However, the class II susceptibility molecule that confers the highest susceptibility in T1D is the HLADQA1*0301/DQB1*0302 (DQ8) dimer. Humanized class II mice devoid of endogenous mouse class II genes and expressing DQ8 have been used to characterize autoantigen epitopes presented by DQ8. $\mathrm{GAD}_{247-266}$ which shows homology with coxsackie P2-C, and $\mathrm{GAD}_{509-528}$-specific, DQ8-restricted Th1 $\mathrm{CD}^{+}{ }^{+} \mathrm{T}$ cell lines were shown to induce insulitis after adoptive transfer into DQ8-expressing mice treated with a very low dose of streptozotocin [77]. Notably, there are two amino acid differences in $\mathrm{GAD}_{247-266}\left(\mathrm{GAD}_{252}\right.$ and $\left.\mathrm{GAD}_{256}\right)$ and one amino acid difference in $\mathrm{GAD}_{509-528}\left(\mathrm{GAD}_{509}\right)$ between the murine and the human sequence. A strong $\mathrm{CD} 4^{+} \mathrm{T}$ cell response was observed and human GAD65 epitopes $\left(\mathrm{GAD}_{497-517}\right.$, $\mathrm{GAD}_{527-547}, \mathrm{GAD}_{537-557}$ ) identified using a pool of 1920 23 mers overlapping peptides spanning two large regions of GAD 65 in transgenic mice expressing DQ8 and backcrossed onto the NOD background for two generations [78].

Following identification of GAD65551-565 as naturally processed and as eliciting a $\mathrm{T}$ cell response in recent-onset T1D patients and individuals at risks [73], soluble HLADR401 or -DR404 TMrs complexed to GAD65 551-565 were used to analyze circulating T-cells from recent-onset T1D patients and at-risk subjects. This allowed detecting high 
avidity $\mathrm{CD} 4^{\text {high }}$ tetramer-positive cells after expansion in vitro and activation on specific plate-bound class II-peptide monomers [79]. Seemingly, expansions were detected in the presence of GAD65 $555-567$ GAD65 $274-286$ peptides, and proinsulin ${ }_{\mathrm{B} 24-\mathrm{C} 36}$, using TMrs. [80]. Generating a panel of GAD65-specific T cell lines from HLA-DR*0301/*0401 recent-onset T1D patients, epitopes have also been identified. Two were presented by DR4-expressing APCs, one covering amino acid residues $270-283$, in close proximity, but outside the homology region shared with Coxsackie virus P2-C protein, a second covering residues 556-575, the peptide largely overlapping with a 20 mer peptide having the highest affinity to DRB1*0401 among known GAD65 peptides. Both were characterized in two T1D patients carrying the high susceptibility HLA-DR*0401/DQB1*0302 haplotype. Two epitopes (GAD ${ }_{146-165}$ and $\left.\mathrm{GAD}_{174-185}\right)$ were presented by APCs expressing the susceptibility HLA-DR* 1601 allele, but one $\left(\mathrm{GAD}_{206-225}\right)$ was presented by APCs expressing the resistance allele HLA-DR*1501 [81].

Among the many GAD epitopes characterized, $\mathrm{GAD}_{555-567}$ has led to extensive studies, both ex vivo and in transgenic mice. The transfer of a DR4-restricted $\mathrm{GAD}_{555-567}$-specific $\mathrm{CD} 4^{+} \mathrm{T}$ cell clone induces insulitis in $\mathrm{Rag}^{-/-} \mathrm{I}-\mathrm{A}^{\mathrm{b}-/-}$ B6 DR4 transgenic mice [82] while $\mathrm{CD}^{+}{ }^{+} \mathrm{T}$ cells carrying TCR transgenes from two distinct $\mathrm{GAD}_{555-567^{-}}$ specific CD4 $\mathrm{T}$ cell clones in B6 DR4-transgenic mice remained tolerant, although through different mechanisms [83]. An increase in the avidity of $\mathrm{CD} 4^{+} \mathrm{T}$ cell recognition of $\mathrm{GAD}_{555-567}$ has been reported in three prediabetic subjects along progression from autoantibody positivity to clinical T1D [84].

In addition to studies of direct interactions of $\mathrm{CD} 4^{+} \mathrm{T}$ cells and class II-restricted peptides, cellular binding assays have been used for studying peptide-class II interactions for a large number of DR and DQ molecules. A clustering of peptides has been identified in the $\mathrm{COOH}$-terminal region of GAD and promiscuous peptides have been identified. Most peptides were further shown to bind both diabetespredisposing and diabetes-protective class II molecules [85-87] and DR as well as DQ molecules [88]. However, limitations in these studies rely with the likelihood that, in contrast with antiviral responses, peptides recognized along the autoimmune response to $\beta$-cells cannot be predicted on an affinity basis [55, 56], many peptides showing low to medium affinity being recognized and inducing immunogenic responses in humanized mice as recently shown in a DQ8 NOD transgenic mouse [89].

Similar strategies have been followed to study $\mathrm{CD} 4^{+} \mathrm{T}$ cell recognition of IA-2 and IGRP. Using libraries of synthetic peptides overlapping the intracytoplasmic domain of IA-2, a dominant epitope recognized by DR4-restricted T cells from subjects at risk for T1D has first been identified, IA-2805-820, which has $100 \%$ similarity with a sequence of the rotavirus VP7 protein [90]. Studying a panel of naturally processed islet epitopes by elution from APCs bearing HLA-DR4, IA-2 ${ }_{652-80}$, IA-2709-35, IA-2 2752-75, IA-2 $793-817$, IA-2 $853-72$, IA-2 $955-76$-specific $\mathrm{CD} 4^{+} \mathrm{T}$ cells have been identified as proinflammatory $\mathrm{T}$ cells. Interestingly in this study, the majority of nondiabetic, HLA-matched controls also showed a response against islet peptides, but with the phenotype profile of IL-10-secreting T cells [48]. Two phogrin DQ8 epitopes (ICA512 $640-659$ and ICA512755-776) previously defined as recognized by diabetogenic T cells in the NOD mouse has been further identified using transgenic mice expressing DQ8 on the NOD background [91]. The evidence for molecular mimicry between an IA-2 (and GAD) epitope and the rotavirus VP7 protein has been further detailed by showing strong binding of both autoantigen and viral peptides to HLA-DRB1*04 and cross recognition by IA-2specific T cells [92]. The 831-860 region of IA-2 frequently recognized by autoantibodies has been shown to be recognized by IL-10-secreting T cells from T1D patients [93]. Following identification of DRA ${ }^{*} 0101 / \mathrm{DRB} 1 * 0401$-retricted IGRP $_{23-35}$ and IGRP $247-259$ and DRA1*0101/DRB1*0301retricted IGRP I $_{13-25}$ and IGRP $226-238$ epitopes, IGRP-specific $\mathrm{CD}^{+}{ }^{+} \mathrm{T}$ cells have been detected in more than $80 \%$ of DRB1*0401 or DRB1*0301 healthy and T1D subjects [94].

Interestingly, autoantigen-specific $\mathrm{CD} 4^{+} \mathrm{T}$ cells have been studied in very different clinical settings, including in autoantibody-positive individuals at risk for T1D, in recent-onset T1D patients and in patients undergoing pancreas/kidney as recently reported in 3 patients [95] or islet transplant [58]. Autoantibodies were detected either pretransplant or reappeared 5 and 6 years posttransplant in still normoglycemic patients, somewhat paralleling insulitis, whatever the immunosuppression used. GAD-specific $\mathrm{CD} 4^{+}$ T cells were detected using DRB1*0405 and DRB4*0101 TMrs and IGRP-specific $\mathrm{CD}^{+}{ }^{+} \mathrm{T}$-cells were detected using HLA-A2/A*0201 class I pentamers along followup. Autoreactive T-cells are temporarily inhibited by immunosuppression, their reappearance is followed by further loss of insulin secretion [95].

3.2. $C D 8^{+} T$ Cells. The first evidence for the recognition of GAD by $A^{*} 0201$-restricted $\mathrm{CD} 8^{+} \mathrm{T}$ cells was obtained in one asymptomatic and two recent diabetic patients. $\mathrm{CD} 8^{+} \mathrm{T}$ cells detected in this study were shown to target HLA-A*0201 peptide $\mathrm{GAD}_{114-123}$ and were cytotoxic to autologous antigen-presenting cells incubated with the $\mathrm{GAD}_{114-123}$ peptide or infected with a recombinant vaccinia virus expressing GAD65 [38]. A list of epitopes along with class I-restricted HLA molecule is provided in Table 4. The recognition of the $\mathrm{GAD}_{114-123}$ epitope was confirmed by another study using an interferon $\gamma$ Elispot assay [96]. Another peptide from IA2 (IA-2 $297-805$ ) was reported as the target of cytotoxic T cells, but both in T1D patients and control individuals [97]. Using algorithms to predict nonameric $\beta$-cell peptides that would bind to the common HLA-A*0201 allele and an interferon $\gamma$ Elispot assay, a human islet amyloid polypeptide (IAPP) precursor protein, 6 out of 9 recent-onset T1D patients, but none of longstanding T1D patients, were shown to recognize preproIAPP peptide $\mathrm{IAPP}_{5-13}$ [98]. Another IAPP peptide $\left(\mathrm{IAPP}_{9-17}\right)$ was defined using the same approach and an assay evaluating granzyme $\mathrm{B}$ secretion, along with IGRP peptides IGRP $_{215-223}$, IGRP ${ }_{152-160}$ IGRP $_{228-236}$ and IGRP $266-273$ glial fibrillary acidic protein (GFAP) peptides GFAP $_{143-151}$ and GFAP ${ }_{214-222}$, IA-2 $172-180$, and IA-2 $482-490$, 
TABLE 4: CD8 ${ }^{+}$T-cell epitopes of human T1D autoantigens (other than preproinsulin).

\begin{tabular}{|c|c|c|c|}
\hline Epitope preproinsulin & MHC restriction & responders & references \\
\hline \multirow{2}{*}{$\mathrm{GAD}_{114-123}$} & \multirow{2}{*}{ HLA-A*0201 } & Recent-onset T1D & \multirow{2}{*}[38,96,103]{} \\
\hline & & Transgenic mice & \\
\hline $\mathrm{GAD}_{114-122}$ & HLA-A*0201 & Recent-onset T1D & {$[101]$} \\
\hline $\mathrm{GAD}_{110-118}$ & HLA-A*0201 & Transgenic mice & {$[103]$} \\
\hline $\mathrm{GAD}_{159-167}$ & HLA-A*0201 & Transgenic mice & {$[103]$} \\
\hline $\mathrm{GAD}_{476-484}$ & HLA-A*0201 & Transgenic mice & {$[103]$} \\
\hline $\mathrm{GAD}_{536-545}$ & HLA-A*0201 & Transgenic mice & {$[103]$} \\
\hline $\mathrm{IAPP}_{5-13}$ & HLA-A*0201 & Recent-onset T1D & {$[98]$} \\
\hline \multirow{3}{*}{$\mathrm{IAPP}_{9-17}$} & & At risk & \multirow{3}{*}[99,100]{} \\
\hline & HLA-A*0201 & Recent-onset T1D & \\
\hline & & T1D & \\
\hline $\mathrm{IGRP}_{215-223}$ & HLA-A*0201 & Recent-onset T1D & {$[100]$} \\
\hline \multirow{2}{*}{$\mathrm{IGRP}_{152-160}$} & \multirow{2}{*}{ HLA-A*0201 } & At risk & \multirow{2}{*}[99,100]{} \\
\hline & & T1D & \\
\hline \multirow{2}{*}{$\mathrm{IGRP}_{228-236}$} & \multirow{2}{*}{ HLA-A*0201 } & Transgenic mice & \multirow{2}{*}[96,102]{} \\
\hline & & Recent-onset T1D & \\
\hline \multirow{2}{*}{$\operatorname{IGRP}_{266-273}$} & \multirow{2}{*}{ HLA-A*0201 } & Transgenic mice & \multirow{2}{*}[96,102]{} \\
\hline & & Recent-onset T1D & \\
\hline $\mathrm{IGRP}_{206-214}$ & HLA-A*0201 & Transgenic mice & {$[102]$} \\
\hline IGRP $_{337-345}$ & HLA-A*0201 & Transgenic mice & {$[102]$} \\
\hline IGRP $_{265-273}$ & HLA-A*0201 & Transgenic mice & {$[102]$} \\
\hline \multirow{2}{*}{ GFAP $_{143-151}$} & \multirow{2}{*}{ HLA-A*0201 } & At risk & [99] \\
\hline & & $\mathrm{T} 1 \mathrm{D}$ & \\
\hline \multirow{2}{*}{ GFAP $_{214-222}$} & \multirow{2}{*}{ HLA-A*0201 } & At risk & \multirow{4}{*}[97]{} \\
\hline & & T1D & \\
\hline \multirow{2}{*}{ IA- $2_{797-805}$} & & Normal subjects & \\
\hline & & Recent-onset T1D & \\
\hline IA- $2_{172-180}$ & HLA-A*0201 & Recent-onset T1D & {$[100]$} \\
\hline IA- $2_{482-490}$ & HLA-A*0201 & Recent-onset T1D & {$[100]$} \\
\hline IA2 $790-798$ & HLA-A*0201 & Transgenic mice & {$[103]$} \\
\hline IA $2_{805-813}$ & HLA-A*0201 & Transgenic mice & {$[103]$} \\
\hline IA $2_{830-839}$ & HLA-A*0201 & Transgenic mice & {$[103]$} \\
\hline IA2 $962-970$ & HLA-A*0201 & Transgenic mice & {$[103]$} \\
\hline
\end{tabular}

$[95,99,100]$. A strong inverse correlation between the binding affinity of $\beta$-cell peptides to HLA-A*0201 and CTL responses against those peptides was observed in recentonset type 1 diabetic patients. These data confirmed that many $\beta$-cell epitopes are recognized by CTLs in recentonset type 1 diabetic patients. Interestingly, IA-2 and GAD have been defined as a key autoantigen in T1D on the basis of the predictive value of anti-IA2 and anti-GAD autoantibodies in prediabetic individuals, while IGRP and IAPP have not been defined as key targets of autoantibodies in $\mathrm{T} 1 \mathrm{D}$ in the human. $\mathrm{GAD}_{114-122}$-specific $\mathrm{CD}^{+} \mathrm{T}$ cells, as well as GAD-specific and insulin-specific CD $4^{+} \mathrm{T}$ cells, have further been detected exclusively in T1D patients within the memory CD45RO ${ }^{+} \mathrm{T}$ cell population while naïve CD45RO T cell stained with HLA- $0201^{*}-\mathrm{GAD}_{114-122}$ tetramers were discriminative between control and T1D patients [101]. A combinatorial quantum dot $\mathrm{MHC}$ multimer technique has further allowed detecting expansions of HLA-A*0201restricted $\mathrm{CD}^{+} \mathrm{T}$ cells that were specific for IA-2797-805, GAD65 $_{114-123}, \mathrm{IGRP}_{265-273}$, and preproIAPP ${ }_{5-13}$ in recent onset diabetes patients, with a specificity ranging from $87 \%$ to $100 \%$ and a sensitivity ranging from $25 \%$ to $40 \%$, and in islet transplantation recipients [60].

The use of HLA-A*0201 transgenic mice has first reported or confirmed the characterization of class I-restricted peptides that are potentially presented to $\mathrm{CD} 8^{+} \mathrm{T}$ cells in the human. IGRP $206-214, \mathrm{IGRP}_{337-345}$ and $\mathrm{IGRP}_{265-273}$ have been identified in HLA-A*0201 transgenic mice on the NOD genetic background and shown to be targeted by pathogenic $\mathrm{CD}^{+} \mathrm{T}$ cells [102]. The systematic immunization of HLA-A*0201 transgenic mice using plasmids encoding GAD65 or the catalytic unit of the intracellular domain of IA-2 has allowed defining 5 GAD peptides $\left(\mathrm{GAD}_{110-118}\right.$, $\mathrm{GAD}_{114-123}, \mathrm{GAD}_{159-167}, \mathrm{GAD}_{476-484}$, and $\left.\mathrm{GAD}_{536-545}\right)$ and 4 IA-2 peptides (IA $2_{790-798}$, IA $2_{805-813}$, IA $2_{830-839}$, and 
IA2 $962-970$ ) that were recognized by $\mathrm{CD}^{+} \mathrm{T}$ cells from T1D patients, 3 of which $\left(\mathrm{GAD}_{114-123}, \mathrm{GAD}_{536-545}\right.$, and IA2 $205-813)$ in more than $25 \%$ patients [103].

Shifts both in frequency and in immunodominance of $\mathrm{CD}^{+} \mathrm{T}$-cell responses have been observed within months following T1D onset and were more rapid than changes in autoantibody titers. Positive T-cell responses to islet epitopes (GAD65 ${ }_{114-123}, \mathrm{GAD}_{536-545}, \mathrm{IGRP}_{228-236}, \mathrm{PPI}_{2-10}$, $\mathrm{PPI}_{34-42}, \mathrm{PPI}_{42-51}$, and $\mathrm{PI}_{101-109}$ ) observed at diagnosis were shown to drop to non detectable levels, while newly targeted epitopes were evidenced, in particular proinsulin $\mathrm{B}_{18-27}$, IA$2_{206-214}$, and IGRP $265-273$. However, of a total of positive Tcell responses to islet epitopes observed at diagnosis, 26 of 42 dropped to nondetectable levels, while new epitopes were targeted in only 5 [32].

3.3. Regulatory $T$ Cells. The role of protective $\mathrm{CD} 4^{+} \mathrm{T}$ cells in T1D has first been defined in the NOD mouse [104]. In the human, initial reports documenting decreased numbers of $\mathrm{CD}^{+}{ }^{+} \mathrm{T}$ regulatory $\left(\mathrm{T}_{\text {reg }}\right)$ cells defined as $\mathrm{CD} 25^{+}[105]$ were not confirmed by later works using more specific surface phenotyping [106]. Few papers addressed the issue of $\mathrm{T}_{\text {reg }}$ by analyzing autoantigen-specific $\mathrm{T}_{\text {reg }}$. Despite the importance of this question, the characterization of islet-specific Tregs is still in its infancy, as it is rather difficult to detect them (their frequency being probably even lower than that of the corresponding effectors) and to expand them in vitro (most of these cells being characterized by a state of anergy that needs to be reversed).

The characterization of both proinflammatory (IFN- $\gamma$ producing) and regulatory (IL-10-producing) $\mathrm{CD} 4^{+} \mathrm{T}$-cell responses against proinsulin and IA-2 indicate that $\mathrm{T}_{\text {reg }}$ are possibly key players. While T1D patients harbored predominant IFN $-\gamma$ responses, healthy subjects were characterized by higher frequencies of IL-10 responses specific for the same epitopes. The same was not true for responses against an irrelevant Ag such as tetanus toxoid. Moreover, T1D patients displaying higher IL-10 responses were characterized by an older age T1D onset, suggesting that these regulatory may counterbalance autoimmune effectors, at least transiently [48]. IL-10-secreting CD4 $4^{+} \mathrm{T}_{\text {reg }}$ specific for proinsulin and IA-2 epitopes have been characterized as suppressive in vitro in healthy subjects. This suppressive activity is however not linked to IL-10 secretion, but rather to elimination of Agpresenting cells [107]. Importantly, we previously showed that GAD-specific effector $\mathrm{CD} 4^{+} \mathrm{T}$ cells cloned from T1D patients could also be rendered anergic and suppressive upon sustained Ag-specific in vitro stimulation [108]. Similar observations were made by showing that patients harboring the protective I/III and III/III insulin VNTR haplotypes displayed a threefold higher IL-10 release in proinsulinspecific memory $\mathrm{T}$ cells. These data are consistent with the hypothesis that VNTR-induced higher insulin levels in the thymus promote Treg generation, offering an additional explanation for the protective effect of the VNTR class III alleles [109]. Seemingly, cloned $\mathrm{PPI}_{70-90}$-specific DRB1*0401-restricted human T cells have been characterized as expressing a downregulatory $\mathrm{T}$ helper 2 phenotype through predominant production of IL- 5 and IL-10 and low interferon $\gamma$ production [110]. DRB ${ }^{*} 0401$-restricted $\mathrm{CD} 4^{+}$ T cells that are specific for GAD65 $555-567$ have been identified in normal individuals using GAD65-specific class II TMrs after expansion in the presence of peptide, following removal of $\mathrm{CD} 4{ }^{+} \mathrm{CD} 25^{+} \mathrm{T}_{\text {reg }}$. Their expansion was reversed adding back $\mathrm{CD}^{+} \mathrm{CD} 25^{+} \mathrm{T}_{\text {reg }}[111,112]$. Taken together, these observations suggest that detection of T-cell autoreactivity should not be considered pathological per se, but should rather be interpreted by functional profiling. Regulatory PIand GAD-specific T-cell clones can be obtained in vitro under standard stimulating conditions in the absence of any exogenous cytokines [113]. Similarly, GAD- and IGRPspecific $\mathrm{CD}^{+}$Treg clones can be obtained by in vitro stimulation of FoxP3-negative $\mathrm{CD} 4^{+} \mathrm{T}$ cells [114]. Whether such clones are only generated in vitro or can also be isolated ex vivo and their mechanism(s) of suppression remain important questions for further investigation. On the same line, there have been reports indicating that GAD-specific circulating $\mathrm{CD}^{+} \mathrm{T}$ cells show an activation phenotype that is not seen in control individuals, likely a memory phenotype and are more prone to proliferate while less dependent on CD28/B7-1 costimulation [115]. GAD65- and proinsulin-specific T-cells, including cells that were specific for $\mathrm{GAD}_{106-125}, \mathrm{GAD}_{526-545}, \mathrm{GAD}_{266-285}, \mathrm{GAD}_{556-575}$, $\mathrm{hPPI}_{72-90}$ and $\mathrm{hPPI}_{94-110}$, have been shown to coexpress CD25 and CD134 (OX40) as a distinctive feature when compared to T cells from healthy subjects [116]. Beyond, $\mathrm{CD}^{+} \mathrm{T}$ cells, polyclonal regulatory $\mathrm{CD}^{+} \mathrm{T}$ cells have also been characterized. $\mathrm{CD}^{+} \mathrm{CD}^{2} 5 \mathrm{RA}^{+} \mathrm{CD}^{+} 7^{-} \mathrm{T}$ cells have been shown to control GAD65-specific $\mathrm{CD}^{+}{ }^{+} \mathrm{T}$ cell expansions through a contact dependent mechanism and the production of IL-10 [117].

\section{Therapeutic Trials Using Peptides or Autoantigens in the Human}

The characterization of T-cell epitopes is expected to help developing $\mathrm{T}$ cell assays to be used in the followup of immunotherapy trials in T1D, thus providing surrogate end point markers of tolerance induction that may prove more reliable than current autoantibody assays $[118,119]$ and pave the way towards antigen or peptide-specific immunotherapy.

4.1. Mechanisms of Tolerance. A major advantage of antigen or peptide-specific immunotherapy over other forms of immunotherapy in human autoimmune diseases is in focusing treatment on self-reactive $\mathrm{T}$ cell clones without impairing immune responses to unrelated antigens, especially tumoral or infectious antigens. In T1D in particular, this may prove of outmost importance considering that insulin therapy has gained in efficacy and safety over years, explaining the progressively decreasing mortality gap between T1D patients and the general population [120]. Although nonspecific immune suppression has been shown partially effective in preserving $\beta$-cells from autoimmune destruction in recentonset T1D patients, immunosuppressive drugs used to suppress the immune response have shown major side effects 
that preclude their use in the long-term range. Peptide and/or antigen-specific immunotherapy is thus likely to allow optimal risk/benefit ratio in T1D.

Immune tolerance is ensured in a succession of checkpoints by a variety of mechanisms affecting differentiating lymphocytes in central lymphoid organs as well as mature lymphocytes in the periphery. Tolerance in the periphery rely on deletion of autoreactive cells, on ignorance of self antigens, on active mechanisms that imprint an intrinsic status on tolerant lymphocytes in the form of anergy or immune deviation and on extrinsic mechanisms that involve regulatory cells. Molecular interactions in the presentation of autoantigen in the periphery are central to the tolerance process and in strategies aiming at restoring or inducing immune tolerance in autoimmunity. Elimination or reprogramming of deleterious autoreactive cells and activation of regulatory cells to control autoimmune effectors are the major outcomes expected from antigen or peptide-specific immunotherapy. These mechanisms have been clearly documented in preclinical models but are only starting to be implemented in human studies.

Key advantages of inducing antigen-specific immune tolerance have been underscored but depend on mechanisms of tolerance induction. First, it may not require knowing the initiating target autoantigen, nor the fine specificity of $\mathrm{T}$ cells involved. Induction of regulatory $\mathrm{T}$ cells, whatever their specificity, may induce bystander immunomodulation within inflammatory sites, for instance, through in situ production of protective cytokines, spreading of Th2 responses or promoting tolerizing antigen presentation. Factors affecting the efficiency of antigen-based immunotherapy include the size of the antigen used, the autoantigen expression pattern, the stage of the disease process at time of administering the tolerizing autoantigen, the crypticity of the epitopes presented, the autoantigen administration route and dose [121].

Given the molecular constraints of $\mathrm{T}$ cell activation, the induction of peptide-specific tolerance is expected to require presentation of specific peptides to autoreactive $\mathrm{CD} 4^{+} \mathrm{T}$ cells in a noninflammatory environment. Induction of immune tolerance by injection of high doses of soluble peptide or antigen or DNA vaccination has proven efficient in experimental models of autoimmunity, but concerns have been raised by the risk of either exacerbating the autoimmune process in some experimental conditions or inducing anaphylactic reactions. The induction of tolerance by the mucosal (oral or nasal) route has seemingly been shown efficient, mostly in preventing autoimmunity, in preclinical models but has failed to apply to human diseases. Mechanisms of action of the mucosal route differ depending on the dose of antigen delivered. The dose chosen in human trials has so far been random. A promising approach to induce tolerance in autoimmune diseases is intravenous injection of antigen-coupled, ethylene carbodiimide-(ECDI) fixed splenocytes. It has shown efficient in animal models, but is more complex to set up in the human. Among mechanisms involved, both the induction of anergy, at least in part through suboptimal costimulatory signaling, and presentation of the tolerizing epitope by plasmacytoid dendritic cells have been evidenced. As a last example, altered peptide ligands (APLs), either antagonistic or partial agonist APLs, have been successfully used in preclinical models to prevent autoimmunity through anergy, immune deviation or bystander suppression. As in case of soluble peptide or antigen, the use of APLs has raised safety issues relating with either exacerbation of autoimmunity or anaphylactic reactions in the human in multiple sclerosis [122]. Deviation of autoimmunity to different targets is another danger that should not be excluded $[1,123$, 124].

4.2. Insulin Trials. As a key autoantigen in T1D, insulin has been used in several trials to downregulate the autoimmune response in recent onset patients or to prevent the full destruction of $\beta$-cells in prediabetic subjects. The first trial ever to modulate $\beta$-cell destruction used intravenous insulin delivered by an external artificial pancreas to maintain glycemic values between 3.3 and $4.4 \mathrm{mmol} / \mathrm{L}$ during 14 days at onset of T1D. This study in $12 \mathrm{~T} 1 \mathrm{D}$ patients was compared to conventional treatment using subcutaneous NPH insulin injections $(n=14)$ and showed significantly higher Cpeptide values in the experimental as compared to the conventional group at one-year. Insulin doses in the experimental group were in the order of $3 \mathrm{U} / \mathrm{kg} / \mathrm{d}$. Mechanisms may have involved $\beta$-cell rest as well immunomodulation through intravenous delivery of insulin [125]. It is possible that efficient metabolic control rather than high insulin doses explain the preservation of $\beta$ cell function in this study. In a comparable study in recent-onset T1D, the nine patients who received high-dose intravenous insulin infusion and the ten patients under intensive-therapy group equally preserved $\beta$ cell function along a one year followup [126]. By contrast, in the DCCT study, intensive insulin therapy allowed maintaining higher C-peptide levels than conventional treatment with one or two injections a day [127]. Fifteen years later, the first randomized, doubleblind crossover study using nasal delivery of insulin in 38 prediabetic, autoantibody-positive individuals showed an increase in anti-insulin antibodies and a decrease in $\mathrm{T}$ cell proliferative responses to insulin, while no acceleration of diabetes development and stable first-phase insulin response to glucose in the 26 individuals who did not develop diabetes was observed at one year [128]. The Diabetes Prevention Trial-Type 1 Diabetes Study [129] screened 84228 first and second-degree relatives of T1D patients to select 3152 autoantibody-positive individuals and assigned 339 with a projected five year risk over $50 \%$ to close observation or low-dose subcutaneous ultralente insulin, $0.25 \mathrm{U} / \mathrm{kg} / \mathrm{d}$ plus annual 4 day courses of continuous intravenous insulin infusions with no delay in diabetes development after a median followup of 3.7 years. In a group of individuals with a five year projected risk of $26 \%-50 \%$, no significant difference in the development of T1D was observed between individuals randomly assigned to oral insulin versus individuals assigned to placebo. However, in a subgroup of individuals with anti-insulin autoantibodies $\geq 80 \mathrm{nU} / \mathrm{mL}$, $6.2 \%$ individuals receiving oral insulin developed T1D, as 
compared to $10.4 \%$ of those receiving placebo $(P<.015)$, suggesting that oral insulin should be tested specifically in this subgroup of individuals [130]. However, a more recent, double-blind, randomised, controlled study in 115 individuals receiving intranasal insulin $(1 \mathrm{U} / \mathrm{kg} / \mathrm{d})$ versus 109 infants and siblings with $\geq 2$ autoantibodies showed no difference between the two groups [131]. It is even possible in this study that nasal insulin had an accelerating effect on T1D development in individuals with $\geq 3$ autoantibodies against different antigen specificities. These data face major caveats. First, the dose of insulin delivered has little rationale. Second, it is likely that prediabetes corresponds to fully activated autoimmunity involving an already expanded $\mathrm{T}$ cell repertoire. In new-onset T1D patients, oral delivery of human insulin at doses ranging from 2.5 to $7.5 \mathrm{mg} / \mathrm{d}$ failed to show any benefit on C-peptide secretion at one year $[132,133]$. Again, new-onset T1D is likely a late stage hardly accessible to down regulation of the autoimmune reaction. Administration of insulin B-chain in incomplete Freund's adjuvant has been shown to elicit strong B and $\mathrm{T}$ cell immune responses to insulin in 12 subjects with recent-onset T1D, but no C-peptide benefit over a two-year followup [134]. Finally, beyond the use of insulin as a key autoantigen to downregulate the autoimmune response to $\beta$-cells in prediabetes and in new-onset T1D, a key issue remains whether or not immediate insulin therapy should be started in noninsulin dependent diabetes patients who are tested positive for islet cell autoantibodies, in particular anti-GAD autoantibodies. Sixty anti-GAD positive patients with a five year non-insulin dependent diabetes profile were randomized to either early insulin or sulfonylureas, tested annually for C-peptide secretion under an oral glucose tolerance test and followed up for 57 months. The progression to insulin dependence was observed in 3 out of 30 patients in the insulin group while in 13 of 30 in the sulfonylurea group [135], in contrast with other studies [136].

4.3. Glutamate Decarboxylase Trials. Following a dosefinding study in patients with latent autoimmune diabetes in adults indicating the safety of a primary injection and a booster injection of $20 \mu \mathrm{g}$ each of recombinant human GAD in a standard vaccine formulation with alum as adjuvant [137], a double-blind randomised study was performed in 35 GAD autoantibody-positive T1D patients who had fasting Cpeptide levels $>0.1 \mathrm{nmol} / \mathrm{L}(0.3 \mathrm{ng} / \mathrm{mL})$ within 18 months of diabetes diagnosis. Patients in the treated group received two injections of GAD at 1 and 30 days of the study. The decrease in fasting C-peptide values and stimulated secretion with time was significantly lower by $23 \%$ and $29 \%$, respectively, in treated versus placebo patients, 30 months after the first GAD injection. No adverse effects were observed. An increase in anti-GAD autoantibodies was seen in patients who received GAD injections and peaked at 3 months of the study. Interleukins $5,10,13$, and 17 , interferon- $\gamma$ and TNF- $\alpha$ production by $\mathrm{T}$ cells in response to GAD in vitro were seen in treated patients, while not in the placebo group [138].
4.4. Heat Shock Protein Trials. Heat shock protein 60 (hsp60) has been discussed following NOD studies as an autoantigen in T1D and T cell clones specific for hsp60 peptide p277 characterized in this model. Several trials have been conducted in the human using a 24-aminoacid peptide derived from the C-terminus of human hsp60 in patients with established T1D, including a trial in children with T1D. While no effect on C-peptide preservation was observed in the pediatric study, one of the randomized study performed in 35 adult T1D patients within $<6$ months following diagnosis reported significant preservation of C-peptide values in the treated group as opposed to significant decrease in placebo-treated patients. T-cell responses showed increased interferon $\gamma$ and decreased interleukin 13 production in response to hsp60 than to p277 and less interferon $\gamma$, more interleukin 10 and 13 in the treated group than in the placebo group [139].

\section{Conclusion}

Developing T-cell assays that allow characterizing diabetes autoimmunity is a major challenge in human T1D. It is expected to help defining epitopes that are recognized in T1D, to pinpoint key functional features of epitope-specific $T$ lymphocytes along the natural history of the diabetes process and to pave the way towards therapeutic strategies to induce immune tolerance to $\beta$-cells. New T-cell technologies are expected to allow defining autoreactive T-cell differentiation programs and characterizing autoimmune responses in comparison to physiologically appropriate immune responses. This may allow additional mechanistic studies and prove instrumental in the discovery of immune correlates of efficacy in clinical trials, as initially reported using autoantibody assays and now an open field for T cell assays.

\section{Acknowledgments}

This work was supported by ANR Grant COD-2005 MELTD1 and PHRC AOR 05034/P051078 (C.B.), Juvenile Diabetes Research Foundation (JDRF Grant no. 1-2008106), the European Foundation for the Study of Diabetes (EFSD/JDRF/Novo Nordisk European Programme in Type 1 Diabetes Research 2007), INSERM Avenir Program (R.M.), and by Inserm-DHOS grant Recherche clinique translationnelle.

\section{References}

[1] B. Faideau, E. Larger, F. Lepault, J. C. Carel, and C. Boitard, "Role of $\beta$-cells in type 1 diabetes pathogenesis," Diabetes, vol. 54, no. 2, pp. S87-S96, 2005.

[2] M. S. Anderson and J. A. Bluestone, "The NOD mouse: a model of immune dysregulation," Annual Review of Immunology, vol. 23, pp. 447-485, 2005.

[3] U. C. Rogner, C. Boitard, J. Morin, E. Melanitou, and P. Avner, "Three loci on mouse chromosome 6 influence onset and final incidence of type I diabetes in NOD.C3H congenic strains," Genomics, vol. 74, no. 2, pp. 163-171, 2001.

[4] J. A. Todd, "Etiology of type 1 diabetes," Immunity, vol. 32, no. 4, pp. 457-467, 2010. 
[5] N. Itoh, T. Hanafusa, A. Miyazaki et al., "Mononuclear cell infiltration and its relation to the expression of major histocompatibility complex antigens and adhesion molecules in pancreas biopsy specimens from newly diagnosed insulindependent diabetes mellitus patients," The Journal of Clinical Investigation, vol. 92, no. 5, pp. 2313-2322, 1993.

[6] N. Somoza, F. Vargas, C. Roura-Mir et al., "Pancreas in recent onset insulin-dependent diabetes mellitus: changes in HLA, adhesion molecules and autoantigens, restricted T cell receptor $\mathrm{V} \beta$ usage, and cytokine profile," The Journal of Immunology, vol. 153, no. 3, pp. 1360-1377, 1994.

[7] A. Willcox, S. J. Richardson, A. J. Bone, A. K. Foulis, and N. G. Morgan, "Analysis of islet inflammation in human type 1 diabetes," Clinical and Experimental Immunology, vol. 155, no. 2, pp. 173-181, 2009.

[8] A. Hanninen, S. Jalkanen, M. Salmi, S. Toikkanen, G. Nikolakaros, and O. Simell, "Macrophages, T cell receptor usage, and endothelial cell activation in the pancreas at the onset of insulin-dependent diabetes mellitus," The Journal of Clinical Investigation, vol. 90, no. 5, pp. 1901-1910, 1992.

[9] G. F. Bottazzo, B. M. Dean, and J. M. McNally, "In situ characterization of autoimmune phenomena and expression of HLA molecules in the pancreas in diabetic insulitis," The New England Journal of Medicine, vol. 313, no. 6, pp. 353-360, 1985.

[10] A. K. Foulis, M. McGill, and M. A. Farquharson, "Insulitis in type 1 (insulin-dependent) diabetes mellitus in manmacrophages, lymphocytes, and interferon- $\gamma$ containing cells," Journal of Pathology, vol. 165, no. 2, pp. 97-103, 1991.

[11] A. Willcox, S. J. Richardson, A. J. Bone, A. K. Foulis, and N. G. Morgan, "Analysis of islet inflammation in human type 1 diabetes," Clinical and Experimental Immunology, vol. 155, no. 2, pp. 173-181, 2009.

[12] B. Conrad, E. Weidmann, G. Trucco et al., "Evidence for superantigen involvement in insulin-dependent diabetes mellitus aetiology," Nature, vol. 371, no. 6495, pp. 351-355, 1994.

[13] S. Martin, D. Wolf-Eichbaum, G. Duinkerken et al., "Development of type 1 diabetes despite severe hereditary B-cell deficiency," The New England Journal of Medicine, vol. 345, no. 14, pp. 1036-1040, 2001.

[14] A. G. Ziegler and G. T. Nepom, "Prediction and pathogenesis in type 1 diabetes," Immunity, vol. 32, no. 4, pp. 468-478, 2010.

[15] R. K. Sibley, D. E. R. Sutherland, F. Goetz, and A. F. Michael, "Recurrent diabetes mellitus in the pancreas iso- and allograft. A light and electron microscopic and immunohistochemical analysis of four cases," Laboratory Investigation, vol. 53, no. 2, pp. 132-144, 1985.

[16] F. Homo-Delarche and C. Boitard, "Autoimmune diabetes: the role of the islets of Langerhans," Immunology Today, vol. 17, no. 10, pp. 456-460, 1996.

[17] D. Daniel, R. G. Gill, N. Schloot, and D. Wegmann, "Epitope specificity, cytokine production profile and diabetogenic activity of insulin-specific T cell clones isolated from NOD mice," European Journal of Immunology, vol. 25, no. 4, pp. 1056-1062, 1995.

[18] K. Thébault-Baumont, D. Dubois-Laforgue, P. Krief et al., "Acceleration of type 1 diabetes mellitus in proinsulin 2deficient NOD mice," The Journal of Clinical Investigation, vol. 111, no. 6, pp. 851-857, 2003.

[19] H. Moriyama, N. Abiru, J. Paronen et al., "Evidence for a primary islet autoantigen (preproinsulin 1) for insulitis and diabetes in the nonobese diabetic mouse," Proceedings of the
National Academy of Sciences of the United States of America, vol. 100, no. 18, pp. 10376-10381, 2003.

[20] M. Nakayama, J. N. Beilke, J. M. Jasinski et al., "Priming and effector dependence on insulin B:9-23 peptide in NOD islet autoimmunity," The Journal of Clinical Investigation, vol. 117, no. 7, pp. 1835-1843, 2007.

[21] T. Yamamoto, E. Yamato, F. Tashiro et al., "Development of autoimmune diabetes in glutamic acid decarboxylase 65 (GAD65) knockout NOD mice," Diabetologia, vol. 47, no. 2, pp. 221-224, 2004.

[22] A. Kubosaki, J. Miura, and A. L. Notkins, "IA-2 is not required for the development of diabetes in NOD mice," Diabetologia, vol. 47, no. 1, pp. 149-150, 2004.

[23] D. Zekzer, F. S. Wong, O. Ayalon et al., "GAD-reactive CD4+ Th1 cells induce diabetes in NOD/SCID mice," The Journal of Clinical Investigation, vol. 101, no. 1, pp. 68-73, 1998.

[24] S. M. Lieberman, A. M. Evans, B. Han et al., "Identification of the $\beta$ cell antigen targeted by a prevalent population of pathogenic CD8 T cells in autoimmune diabetes," Proceedings of the National Academy of Sciences of the United States of America, vol. 100, no. 14, pp. 8384-8388, 2003.

[25] K. Haskins and M. McDuffie, "Acceleration of diabetes in young NOD mice with a CD4 islet-specific T cell clone," Science, vol. 249, no. 4975, pp. 1433-1436, 1990.

[26] B. D. Stadinski, T. Delong, N. Reisdorph et al., "Chromogranin A is an autoantigen in type 1 diabetes," Nature Immunology, vol. 11, no. 3, pp. 225-231, 2010.

[27] L. Yu, D. T. Robles, N. Abiru et al., "Early expression of antiinsulin autoantibodies of humans and the NOD mouse: evidence for early determination of subsequent diabetes," Proceedings of the National Academy of Sciences of the United States of America, vol. 97, no. 4, pp. 1701-1706, 2000.

[28] A. G. Ziegler, M. Hummel, M. Schenker, and E. Bonifacio, "Autoantibody appearance and risk for development of childhood diabetes in offspring of parents with type 1 diabetes: the 2-year analysis of the German BABYDIAB Study," Diabetes, vol. 48, no. 3, pp. 460-468, 1999.

[29] R. J. Keller, "Cellular immunity to human insulin in individuals at high risk for the development of type I diabetes mellitus," Journal of Autoimmunity, vol. 3, no. 3, pp. 321-327, 1990.

[30] D. Dubois-LaForgue, J. C. Carel, P. F. Bougnères, J. G. Guillet, and C. Boitard, "T-cell response to proinsulin and insulin in type 1 and pretype 1 diabetes," Journal of Clinical Immunology, vol. 19, no. 2, pp. 127-134, 1999.

[31] N. C. Schloot, B. O. Roep, D. Wegmann et al., "Altered immune response to insulin in newly diagnosed compared to insulin-treated diabetic patients and healthy control subjects," Diabetologia, vol. 40, no. 5, pp. 564-572, 1997.

[32] E. Martinuzzi, G. Novelli, M. Scotto et al., "The frequency and immunodominance of islet-specific CD8 Tcell responses change after type 1 diabetes diagnosis and treatment," Diabetes, vol. 57, no. 5, pp. 1312-1320, 2008.

[33] G. Rudy, N. Stone, L. C. Harrison et al., "Similar peptides from two beta cell autoantigens, proinsulin and glutamic acid decarboxylase, stimulate T cells of individuals at risk for insulin-dependent diabetes," Molecular Medicine, vol. 1, no. 6, pp. 625-633, 1995.

[34] D. G. Alleva, P. D. Crowe, L. Jin et al., "A diseaseassociated cellular immune response in type 1 diabetics to an immunodominant epitope of insulin," The Journal of Clinical Investigation, vol. 107, no. 2, pp. 173-180, 2001.

[35] L. D. Petersen, G. Duinkerken, G. J. Bruining, R. A. W. Van Lier, R. R. P. De Vries, and B. O. Roep, "Increased numbers of 
in vivo activated T cells in patients with recent onset insulindependent diabetes mellitus," Journal of Autoimmunity, vol. 9, no. 6, pp. 731-737, 1996.

[36] I. Durinovic-Belló, M. Schlosser, M. Riedl et al., "Pro- and anti-inflammatory cytokine production by autoimmune $\mathrm{T}$ cells against preproinsulin in HLA-DRB1 ${ }^{*} 04$, DQ8 Type 1 diabetes," Diabetologia, vol. 47, no. 3, pp. 439-450, 2004.

[37] P. Naquet, J. Ellis, D. Tibensky et al., "T cell autoreactivity to insulin in diabetic and related non-diabetic individuals," The Journal of Immunology, vol. 140, no. 8, pp. 2569-2578, 1988.

[38] P. Panina-Bordignon, R. Lang, P. M. Van Endert et al., "Cytotoxic T cells specific for glutamic acid decarboxylase in autoimmune diabetes," Journal of Experimental Medicine, vol. 181, no. 5, pp. 1923-1927, 1995.

[39] S. E. Fineberg, T. T. Kawabata, D. Finco-Kent, R. J. Fountaine, G. L. Finch, and A. S. Krasner, "Immunological responses to exogenous insulin," Endocrine Reviews, vol. 28, no. 6, pp. 625-652, 2007.

[40] I. Durinovic-Bellò, M. Hummel, and A. G. Ziegler, "Cellular immune response to diverse islet cell antigens in IDDM," Diabetes, vol. 45, no. 6, pp. 795-800, 1996.

[41] I. Durinovic-Bellò, M. Hummel, and A. G. Ziegler, "Cellular immune response to diverse islet cell antigens in IDDM," Diabetes, vol. 45, no. 6, pp. 795-800, 1996.

[42] T. I. M. Tree, G. Duinkerken, S. Willemen, R. R. P. De Vries, and B. O. Roep, "HLA-DQ-regulated T-cell responses to islet cell autoantigens insulin and GAD65," Diabetes, vol. 53, no. 7, pp. 1692-1699, 2004.

[43] T. P. Di Lorenzo, M. Peakman, and B. O. Roep, “Translational mini-review series on type 1 diabetes: systematic analysis of $\mathrm{T}$ cell epitopes in autoimmune diabetes," Clinical and Experimental Immunology, vol. 148, no. 1, pp. 1-16, 2007.

[44] R. Raju, S. R. Munn, and C. S. David, "T cell recognition of human pre-proinsulin peptides depends on the polymorphism at HLA DQ locus: a study using HLA DQ8 and DQ6 transgenic mice," Human Immunology, vol. 58, no. 1, pp. 2129, 1997.

[45] M. Congia, S. Patel, A. P. Cope, S. De Virgiliis, and G. Sønderstrup, "T cell epitopes of insulin defined in HLADR4 transgenic mice are derived from preproinsulin and proinsulin," Proceedings of the National Academy of Sciences of the United States of America, vol. 95, no. 7, pp. 3833-3838, 1998.

[46] K. H. Lee, K. W. Wucherpfennig, and D. C. Wiley, "Structure of a human insulin peptide-HLA-DQ8 complex and susceptibility to type I diabetes," Nature Immunology, vol. 2, no. 6, pp. 501-507, 2001.

[47] E. Havari, A. M. Lennon-Dumenil, L. Klein et al., "Expression of the B7.1 costimulatory molecule on pancreatic $\beta$ cells abrogates the requirement for CD4 $\mathrm{T}$ cells in the development, of type 1 diabetes," The Journal of Immunology, vol. 173, no. 2, pp. 787-796, 2004.

[48] S. Arif, T. I. Tree, T. P. Astill et al., "Autoreactive T cell responses show proinflammatory polarization in diabetes but a regulatory phenotype in health," The Journal of Clinical Investigation, vol. 113, no. 3, pp. 451-463, 2004.

[49] S. I. Mannering, L. C. Harrison, N. A. Williamson et al., "The insulin A-chain epitope recognized by human $\mathrm{T}$ cells is posttranslationally modified," Journal of Experimental Medicine, vol. 202, no. 9, pp. 1191-1197, 2005.

[50] S. C. Kent, Y. Chen, L. Bregoli et al., "Expanded T cells from pancreatic lymph nodes of type 1 diabetic subjects recognize an insulin epitope," Nature, vol. 435, no. 7039, pp. 224-228, 2005.
[51] P. E. Jensen, "Reduction of disulfide bonds during antigen processing: evidence from a thiol-dependent insulin determinant," Journal of Experimental Medicine, vol. 174, no. 5, pp. 1121-1130, 1991.

[52] G. G. Miller, J. F. Hoy, L. J. Nell, and J. W. Thomas, "Antigen processing and the human $\mathrm{T}$ cell receptor repertoire for insulin," The Journal of Immunology, vol. 141, no. 10, pp. 3293-3298, 1988.

[53] L. Chang, L. Kjer-Nielsen, S. Flynn et al., "Novel strategy for identification of candidate cytotoxic T-cell epitopes from human preproinsulin," Tissue Antigens, vol. 62, no. 5, pp. 408-417, 2003.

[54] Y. Hassainya, F. Garcia-Pons, R. Kratzer et al., "Identification of naturally processed HLA-A2 - restricted proinsulin epitopes by reversed immunology," Diabetes, vol. 54, no. 7, pp. 2053-2059, 2005.

[55] A. Toma, S. Haddouk, J. P. Briand et al., "Recognition of a subregion of human proinsulin by class I-restricted T cells in type 1 diabetic patients," Proceedings of the National Academy of Sciences of the United States of America, vol. 102, no. 30, pp. 10581-10586, 2005.

[56] A. Toma, T. Laika, S. Haddouk et al., "Recognition of human proinsulin leader sequence by class I-restricted Tcells in HLA-A $* 0201$ transgenic mice and in human type 1 diabetes," Diabetes, vol. 58, no. 2, pp. 394-402, 2009.

[57] A. Skowera, R. J. Ellis, R. Varela-Calviño et al., "CTLs are targeted to kill $\beta$ cells in patients with type 1 diabetes through recognition of a glucose-regulated preproinsulin epitope," The Journal of Clinical Investigation, vol. 118, no. 10, pp. 3390-3402, 2008.

[58] G. G. M. Pinkse, O. H. M. Tysma, C. A. M. Bergen et al., "Autoreactive CD8 T cells associated with $\beta$ cell destruction in type 1 diabetes," Proceedings of the National Academy of Sciences of the United States of America, vol. 102, no. 51, pp. 18425-18430, 2005.

[59] E. Larger, C. Becourt, J. F. Bach, and C. Boitard, "Pancreatic islet $\beta$ cells drive $\mathrm{T}$ cell-immune responses in the nonobese diabetic mouse model," Journal of Experimental Medicine, vol. 181, no. 5, pp. 1635-1642, 1995.

[60] J. H. Velthuis, W. W. Unger, J. R. F. Abreu et al., "Simultaneous detection of circulating autoreactive $\mathrm{CD}^{+} \mathrm{T}$-cells specific for different islet cell-associated epitopes using combinatorial MHC multimers," Diabetes, vol. 59, no. 7, pp. 1721-1730, 2010.

[61] M. Peakman, T. I. Tree, J. Endl, P. Van Endert, M. A. Atkinson, and B. O. Roep, "Characterization of preparations of GAD65, proinsulin, and the islet tyrosine phosphatase IA-2 for use in detection of autoreactive T-cells in type 1 diabetes: report of phase II of the second international immunology of diabetes society workshop for standardization of T-cell assays in type 1 diabetes," Diabetes, vol. 50, no. 8, pp. 1749-1754, 2001.

[62] M. S. Lan, J. Lu, Y. Goto, and A. L. Notkins, "Molecular cloning and identification of a receptor-type protein tyrosine phosphatase, IA-2, from human insulinoma," DNA and Cell Biology, vol. 13, no. 5, pp. 505-514, 1994.

[63] D. U. Rabin, S. M. Pleasic, J. A. Shapiro et al., "Islet cell antigen 512 is a diabetes-specific islet autoantigen related to protein tyrosine phosphatases," The Journal of Immunology, vol. 152, no. 6, pp. 3183-3188, 1994.

[64] H. J. DeAizpurua, M. C. Honeyman, L. C. Harrison et al., "Glutamic acid decarboxylase (GAD) in fetal pig proislets is recognised by antibodies and stimulates $\mathrm{T}$ cells from humans 
with pre-clinical insulindependent diabetes mellitus," Journal of Autoimmunity, vol. 5, pp. 759-770, 1992.

[65] L. C. Harrison, M. C. Honeyman, H. J. DeAizpurua et al., "Inverse relation between humoral and cellular immunity to glutamic acid decarboxylase in subjects at risk of insulindependent diabetes," The Lancet, vol. 341, no. 8857, pp. 1365-1369, 1993.

[66] T. Lohmann, R. D. G. Leslie, M. Hawa, M. Geysen, S. Rodda, and M. Londei, "Immunodominant epitopes of glutamic acid decarboxylase 65 and 67 in insulin-dependent diabetes mellitus," The Lancet, vol. 343, no. 8913, pp. 1607-1608, 1994.

[67] M. C. Honeyman, D. S. Cram, and L. C. Harrison, "Glutamic acid decarboxylase 67-reactive T cells: a marker of insulindependent diabetes," Journal of Experimental Medicine, vol. 177, no. 2, pp. 535-540, 1993.

[68] M. A. Atkinson, D. L. Kaufman, L. Campbell et al., "Response of peripheral-blood mononuclear cells to glutamate decarboxylase in insulin-dependent diabetes," The Lancet, vol. 339, no. 8791, pp. 458-459, 1992.

[69] L. C. Harrison, M. C. Honeyman, H. J. DeAizpurua et al., "Inverse relation between humoral and cellular immunity to glutamic acid decarboxylase in subjects at risk of insulindependent diabetes," The Lancet, vol. 341, no. 8857, pp. 1365-1369, 1993.

[70] M. A. Atkinson, M. A. Bowman, L. Campbell, B. L. Darrow, D. L. Kaufman, and N. K. Maclaren, "Cellular immunity to a determinant common to glutamate decarboxylase and Coxsackie virus in insulin-dependent diabetes," The Journal of Clinical Investigation, vol. 94, no. 5, pp. 2125-2129, 1994.

[71] L. C. Harrison, "Antigen-specific therapy for autoimmune disease: prospects for the prevention of insulin-dependent diabetes," Molecular Medecine, vol. 1, no. 7, pp. 722-727, 1995.

[72] M. C. Honeyman, N. L. Stone, and L. C. Harrison, "T-cell epitopes in type 1 diabetes autoantigen tyrosine phosphatase IA- 2: potential for mimicry with rotavirus and other environmental agents," Molecular Medicine, vol. 4, no. 4, pp. 231-239, 1998.

[73] P. A. Ott, B. A. Herzog, S. Quast et al., "Islet-cell antigenreactive $\mathrm{T}$ cells show different expansion rates and Th1/Th2 differentiation in type 1 diabetic patients and healthy controls," Clinical Immunology, vol. 115, no. 1, pp. 102-114, 2005.

[74] L. S. Wicker, S. L. Chen, G. T. Nepom et al., "Naturally processed $\mathrm{T}$ cell epitopes from human glutamic acid decarboxylase identified using mice transgenic for the type 1 diabetesassociated human MHC class II allele, DRB1*0401," The Journal of Clinical Investigation, vol. 98, no. 11, pp. 25972603, 1996.

[75] S. D. Patel, A. P. Cope, M. Congia et al., "Identification of immunodominant $\mathrm{T}$ cell epitopes of human glutamic acid decarboxylase 65 by using HLA-DR $\left(\alpha 1^{*} 0101, \beta 1^{*} 0401\right)$ transgenic mice," Proceedings of the National Academy of Sciences of the United States of America, vol. 94, no. 15, pp. 8082-8087, 1997.

[76] G. T. Nepom, J. D. Lippolis, F. M. White et al., "Identification and modulation of a naturally processed $\mathrm{T}$ cell epitope from the diabetes-associated autoantigen human glutamic acid decarboxylase 65 (hGAD65)," Proceedings of the National Academy of Sciences of the United States of America, vol. 98, no. 4, pp. 1763-1768, 2001.
[77] L. I. Wen, F. S. Wong, L. Burkly et al., "Induction of insulitis by glutamic acid decarboxylase peptide-specific and HLADQ8-restricted CD4 T cells from human DQ transgenic mice," The Journal of Clinical Investigation, vol. 102, no. 5, pp. 947-957, 1998.

[78] R. S. Abraham, S. B. Wilson, N. F. De Souza, J. L. Strominger, S. R. Munn, and C. S. David, "NOD background genes influence T cell responses to GAD 65 in HLA-DQ8 transgenic mice," Human Immunology, vol. 60, no. 7, pp. 583-590, 1999.

[79] H. Reijonen, E. J. Novak, S. Kochik et al., "Detection of GAD65-specific T-cells by major histocompatibility complex class II tetramers in type 1 diabetic patients and at-risk subjects," Diabetes, vol. 51, no. 5, pp. 1375-1382, 2002.

[80] V. Öling, J. Marttila, J. Ilonen et al., "GAD65- and proinsulinspecific CD4 T-cells detected by MHC class II tetramers in peripheral blood of type 1 diabetes patients and at-risk subjects," Journal of Autoimmunity, vol. 25, no. 3, pp. 235243, 2005.

[81] J. Endl, H. Otto, G. Jung et al., "Identification of naturally processed $\mathrm{T}$ cell epitopes from glutamic acid decarboxylase presented in the context of HLA-DR alleles by T lymphocytes of recent onset IDDM patients," The Journal of Clinical Investigation, vol. 99, no. 10, pp. 2405-2415, 1997.

[82] J. A. Gebe, K. A. Unrath, B. B. Yue, T. Miyake, B. A. Falk, and G. T. Nepom, "Autoreactive human T-cell receptor initiates insulitis and impaired glucose tolerance in HLA DR4 transgenic mice," Journal of Autoimmunity, vol. 30, no. 4, pp. 197-206, 2008.

[83] J. A. Gebe, B. B. Yue, K. A. Unrath, B. A. Falk, and G. T. Nepom, "Restricted autoantigen recognition associated with deletional and adaptive regulatory mechanisms," The Journal of Immunology, vol. 183, no. 1, pp. 59-65, 2009.

[84] N. E. Standifer, E. A. Burwell, V. H. Gersuk, C. J. Greenbaum, and G. T. Nepom, "Changes in autoreactive T cell avidity during type 1 diabetes development," Clinical Immunology, vol. 132, no. 3, pp. 312-320, 2009.

[85] A. Geluk, K. E. Van Meijgaarden, N. C. Schloot, J. W. Drijfhout, T. H. M. Ottenhoff, and B. O. Roep, "HLA-DR binding analysis of peptides from islet antigens in IDDM," Diabetes, vol. 47, no. 10, pp. 1594-1601, 1998.

[86] E. Harfouch-Hammoud, T. Walk, H. Otto et al., "Identification of peptides from autoantigens GAD65 and IA-2 that bind to HLA class II molecules predisposing to or protecting from type 1 diabetes," Diabetes, vol. 48, no. 10, pp. 19371947, 1999.

[87] G. Fenalti, C. S. Hampe, Y. Arafat et al., "COOH-terminal clustering of autoantibody and T-cell determinants on the structure of GAD65 provide insights into the molecular basis of autoreactivity," Diabetes, vol. 57, no. 5, pp. 1293-1301, 2008.

[88] X. Ge, J. D. Piganelli, H. M. Tse et al., "Modulatory role of DR4- to DQ8-restricted CD4 T-cell responses and type 1 diabetes susceptibility," Diabetes, vol. 55, no. 12, pp. 34553462, 2006.

[89] K. Y. Chang and E. R. Unanue, "Prediction of HLADQ8 $\beta$ cell peptidome using a computational program and its relationship to autoreactive T cells," International Immunology, vol. 21, no. 6, pp. 705-713, 2009.

[90] M. C. Honeyman, N. L. Stone, and L. C. Harrison, "T-cell epitopes in type 1 diabetes autoantigen tyrosine phosphatase IA- 2: potential for mimicry with rotavirus and other environmental agents," Molecular Medicine, vol. 4, no. 4, pp. 231-239, 1998. 
[91] K. Kelemen, P. A. Gottlieb, A. L. Putnam, H. W. Davidson, D. R. Wegmann, and J. C. Hutton, "HLA-DQ8-associated T cell responses to the diabetes autoantigen phogrin (IA-2 $\beta$ ) in human prediabetes," The Journal of Immunology, vol. 172, no. 6, pp. 3955-3962, 2004.

[92] M. C. Honeyman, N. L. Stone, B. A. Falk, G. Nepom, and L. C. Harrison, "Evidence for molecular mimicry between human $\mathrm{T}$ cell epitopes in rotavirus and pancreatic islet autoantigens," The Journal of Immunology, vol. 184, no. 4, pp. 2204-2210, 2010.

[93] S. M. Weenink, J. Lo, C. R. Stephenson et al., "Autoantibodies and associated T-cell responses to determinants within the 831-860 region of the autoantigen IA-2 in Type 1 diabetes," Journal of Autoimmunity, vol. 33, no. 2, pp. 147-154, 2009.

[94] J. Yang, N. A. Danke, D. Berger et al., "Islet-specific glucose-6-phosphatase catalytic subunit-related proteinreactive $\mathrm{CD}^{+} \mathrm{T}$ cells in human subjects," The Journal of Immunology, vol. 176, no. 5, pp. 2781-2789, 2006.

[95] F. Vendrame, A. Pileggi, E. Laughlin et al., "Recurrence of type 1 diabetes after simultaneous pancreas-kidney transplantation, despite immunosuppression, is associated with autoantibodies and pathogenic autoreactive CD4 T-cells," Diabetes, vol. 59, no. 4, pp. 947-957, 2010.

[96] R. Mallone, E. Martinuzzi, P. Blancou et al., "CD8+ T-cell responses identify $\beta$-cell autoimmunity in human type 1 diabetes," Diabetes, vol. 56, no. 3, pp. 613-621, 2007.

[97] K. Takahashi, M. C. Honeyman, and L. C. Harrison, "Cytotoxic T cells to an epitope in the islet autoantigen IA2 are not disease-specific," Clinical Immunology, vol. 99, no. 3, pp. 360-364, 2001.

[98] C. Panagiotopoulos, H. Qin, R. Tan, and C. B. Verchere, "Identification of a $\beta$-cell-specific HLA class I restricted epitope in type 1 diabetes," Diabetes, vol. 52, no. 11, pp. 26472651, 2003.

[99] N. E. Standifer, Q. Ouyang, C. Panagiotopoulos et al., "Identification of novel HLA-A*0201-restricted epitopes in recent-onset type 1 diabetic subjects and antibody-positive relatives," Diabetes, vol. 55, no. 11, pp. 3061-3067, 2006.

[100] Q. Ouyang, N. E. Standifer, H. Qin et al., "Recognition of HLA class I-restricted $\beta$-cell epitopes in type 1 diabetes," Diabetes, vol. 55, no. 11, pp. 3068-3074, 2006.

[101] P. Monti, M. Scirpoli, A. Rigamonti et al., "Evidence for in vivo primed and expanded autoreactive $\mathrm{T}$ cells as a specific feature of patients with type 1 diabetes," The Journal of Immunology, vol. 179, no. 9, pp. 5785-5792, 2007.

[102] T. Takaki, M. P. Marron, C. E. Mathews et al., "HLA-A*0201restricted $\mathrm{T}$ cells from humanized NOD mice recognize autoantigens of potential clinical relevance to type 1 diabetes," The Journal of Immunology, vol. 176, no. 5, pp. 32573265, 2006.

[103] P. Blancou, R. Mallone, E. Martinuzzi et al., "Immunization of HLA class I transgenic mice identifies autoantigenic epitopes eliciting dominant responses in type 1 diabetes patients," The Journal of Immunology, vol. 178, no. 11, pp. 7458-7466, 2007.

[104] C. Boitard, R. Yasunami, M. Dardenne et al., "T cellmediated inhibition of the transfer of autoimmune diabetes in NOD mice," The Journal of Experimental Medecine, vol. 169, no. 5, pp. 1669-1680, 1989.

[105] A. Kukreja, G. Cost, J. Marker et al., "Multiple immunoregulatory defects in type-1 diabetes," The Journal of Clinical Investigation, vol. 109, no. 1, pp. 131-140, 2002.

[106] W. Liu, A. L. Putnam, Z. Xu-yu et al., "CD127 expression inversely correlates with FoxP3 and suppressive function of human CD4+ T reg cells," Journal of Experimental Medicine, vol. 203, no. 7, pp. 1701-1711, 2006.

[107] T. I. M. Tree, J. Lawson, H. Edwards et al., "Naturally arising human CD4+ T-cells that recognize islet autoantigens and secrete interleukin-10 regulate proinflammatory T-cell responses via linked suppression," Diabetes, vol. 59, no. 6, pp. 1451-1460, 2010.

[108] R. Mallone, S. A. Kochik, H. Reijonen et al., "Functional avidity directs T-cell fate in autoreactive CD4+ T cells," Blood, vol. 106, no. 8, pp. 2798-2805, 2005.

[109] I. Durinovic-Belló, E. Jelinek, M. Schlosser et al., "Class III alleles at the insulin VNTR polymorphism are associated with regulatory T-cell responses to proinsulin epitopes in HLA-DR4, DQ8 individuals," Diabetes, vol. 54, supplement 2, pp. S18-S24, 2005.

[110] I. Durinovic-Belló, S. Rosinger, J. A. Olson et al., "DRB1*0401-restricted human $\mathrm{T}$ cell clone specific for the major proinsulin 73-90 epitope expresses a downregulatory T helper 2 phenotype," Proceedings of the National Academy of Sciences of the United States of America, vol. 103, no. 31, pp. 11683-11688, 2006.

[111] N. A. Danke, J. Yang, C. Greenbaum, and W. W. Kwok, "Comparative study of GAD65-specific CD4+ T cells in healthy and type 1 diabetic subjects," Journal of Autoimmunity, vol. 25, no. 4, pp. 303-311, 2005.

[112] N. A. Danke, D. M. Koelle, C. Yee, S. Beheray, and W. W. Kwok, "Autoreactive T cells in healthy individuals," The Journal of Immunology, vol. 172, no. 10, pp. 5967-5972, 2004.

[113] J. A. Dromey, B. H. Lee, H. Yu et al., "Generation and expansion of regulatory human CD4(+) T-cell clones specific for pancreatic islet autoantigens," Journal of Autoimmunity, vol. 36, no. 1, pp. 47-55, 2011.

[114] S. A. Long, K. Cerosaletti, P. L. Bollyky et al., "Defects in IL-2R signaling contribute to diminished maintenance of FOXP3 expression in CD4(+)CD25(+) regulatory T-cells of type 1 diabetic subjects," Diabetes, vol. 59, no. 2, pp. 407-415, 2010.

[115] V. Viglietta, S. C. Kent, T. Orban, and D. A. Hafler, "GAD65reactive $\mathrm{T}$ cells are activated in patients with autoimmune type 1a diabetes," The Journal of Clinical Investigation, vol. 109, no. 7, pp. 895-903, 2002.

[116] J. Endl, S. Rosinger, B. Schwarz et al., "Coexpression of CD25 and OX40 (CD134) receptors delineates autoreactive T-cells in type 1 diabetes," Diabetes, vol. 55, no. 1, pp. 50-60, 2006.

[117] E. A. James and W. W. Kwok, "CD8 suppressor-mediated regulation of human $\mathrm{CD} 4+\mathrm{T}$ cell responses to glutamic acid decarboxylase 65," European Journal of Immunology, vol. 37, no. 1, pp. 78-86, 2007.

[118] C. Boitard, G. Feutren, L. Castano et al., "Effect of cyclosporin A treatment on the production of antibody in insulin-dependent (type I) diabetic patients," The Journal of Clinical Investigation, vol. 80, no. 6, pp. 1607-1612, 1987.

[119] B. O. Roep and M. Peakman, "Surrogate end points in the design of immunotherapy trials: emerging lessons from type 1 diabetes," Nature Reviews Immunology, vol. 10, no. 2, pp. $145-152,2010$.

[120] A. M. Secrest, D. J. Becker, S. F. Kelsey, R. E. LaPorte, and T. J. Orchard, "Cause-specific mortality trends in a large population-based cohort with long-standing childhoodonset type 1 diabetes," Diabetes, vol. 59, no. 12, pp. 32163222, 2010.

[121] J. Tian and D. L. Kaufman, "Antigen-based therapy for the treatment of type 1 diabetes," Diabetes, vol. 58, no. 9, pp. 1939-1946, 2009. 
[122] S. D. Miller, D. M. Turley, and J. R. Podojil, "Antigenspecific tolerance strategies for the prevention and treatment of autoimmune disease," Nature Reviews Immunology, vol. 7, no. 9, pp. 665-677, 2007.

[123] B. Salomon, L. Rhee, H. Bour-Jordan et al., "Development of spontaneous autoimmune peripheral polyneuropathy in B7-2-deficient NOD mice," Journal of Experimental Medicine, vol. 194, no. 5, pp. 677-684, 2001.

[124] N. Prevot, C. Briet, and H. Lassmann, "Abrogation of ICOS/ICOSL costimulation in NOD mice results in autoimmune deviation towards the neuromuscular system," European Journal of Immunology, vol. 40, pp. 2267-2276, 2010.

[125] S. C. Shah, J. I. Malone, and N. E. Simpson, "A randomized trial of intensive insulin therapy in newly diagnosed insulindependent diabetes mellitus," The New England Journal of Medicine, vol. 320, no. 9, pp. 550-554, 1989.

[126] O. Schnell, B. Eisfelder, E. Standl et al., "High-dose intravenous insulin infusion versus intensive insulin treatment in newly diagnosed IDDM," Diabetes, vol. 46, no. 10, pp. 16071611, 1997.

[127] The Diabetes Control and Complications Trial, "Effect of intensive therapy on residual $\beta$-cell function in patients with type 1 diabetes in the Diabetes Control and Complications Trial," Annals of Internal Medecine, vol. 128, pp. 517-523, 1998.

[128] L. C. Harrison, M. C. Honeyman, C. E. Steele et al., "Pancreatic $\beta$-cell function and immune responses to insulin after administration of intranasal insulin to humans at risk for type 1 diabetes," Diabetes Care, vol. 27, no. 10, pp. 2348 2355, 2004.

[129] diabetes Prevention Trial-Type 1 Diabetes Study Group, "Effects of insulin in relatives of patients with Type 1 Diabetes Mellitus," The New England Journal of Medecine, vol. 346, pp. 1685-1691, 2002.

[130] J. S. Skyler, J. P. Krischer, and J. Wolfsdorf, "Effects of oral insulin in relatives of patients with type 1 diabetes: the diabetes prevention trial-type 1," Diabetes Care, vol. 28, no. 5, pp. 1068-1076, 2005.

[131] K. Näntö-Salonen, A. Kupila, S. Simell et al., "Nasal insulin to prevent type 1 diabetes in children with HLA genotypes and autoantibodies conferring increased risk of disease: a doubleblind, randomised controlled trial," The Lancet, vol. 372, no. 9651, pp. 1746-1755, 2008.

[132] L. Chaillous, H. Lefèvre, C. Thivolet et al., "Oral insulin administration and residual $\beta$-cell function in recent-onset type 1 diabetes: a multicentre randomised controlled trial," The Lancet, vol. 356, no. 9229, pp. 545-549, 2000.

[133] P. Pozzilli, D. Pitocco, N. Visalli et al., "No effect of oral insulin on residual beta-cell function in recent-onset Type I diabetes (the IMDIAB VII)," Diabetologia, vol. 43, no. 8, pp. 1000-1004, 2000.

[134] T. Orban, K. Farkas, H. Jalahej et al., "Autoantigen-specific regulatory $\mathrm{T}$ cells induced in patients with type 1 diabetes mellitus by insulin B-chain immunotherapy," Journal of Autoimmunity, vol. 34, no. 4, pp. 408-415, 2010.

[135] T. Maruyama, S. Tanaka, A. Shimada et al., "Insulin intervention in slowly progressive insulin-dependent (type 1) diabetes mellitus," Journal of Clinical Endocrinology and Metabolism, vol. 93, no. 6, pp. 2115-2121, 2008.

[136] M. Alvarsson, G. Sundkvist, I. Lager et al., "Effects of insulin vs. glibenclamide in recently diagnosed patients with type 2 diabetes: a 4-year follow-up," Diabetes, Obesity and Metabolism, vol. 10, no. 5, pp. 421-429, 2008.
[137] C. D. Agardh, C. M. Cilio, A. Lethagen et al., "Clinical evidence for the safety of GAD65 immunomodulation in adult-onset autoimmune diabetes," Journal of Diabetes and its Complications, vol. 19, no. 4, pp. 238-246, 2005.

[138] J. Ludvigsson, M. Faresjö, M. Hjorth et al., "GAD treatment and insulin secretion in recent-onset type 1 diabetes," The New England Journal of Medicine, vol. 359, no. 18, pp. 19091920, 2008

[139] I. Raz, D. Elias, A. Avron, M. Tamir, M. Metzger, and I. R. Cohen, " $\beta$-cell function in new-onset type 1 diabetes and immunomodulation with a heat-shock protein peptide (DiaPep277): a randomised, double-blind, phase II trial," The Lancet, vol. 358, no. 9295, pp. 1749-1753, 2001.

[140] G. Semana, R. Gausling, R. A. Jackson, and D. A. Hafler, “T cell autoreactivity to proinsulin epitopes in diabetic patients and healthy subjects," Journal of Autoimmunity, vol. 12, no. 4, pp. 259-267, 1999.

[141] I. Durinovic-Belló, B. O. Boehm, and A. G. Ziegler, "Predominantly recognized ProInsulin T helper cell epitopes in individuals with and without islet cell autoimmunity," Journal of Autoimmunity, vol. 18, no. 1, pp. 55-66, 2002.

[142] K. Kimura, T. Kawamura, S. Kadotani, H. Inada, S. Niihira, and T. Yamano, "Peptide-specific cytotoxicity of T lymphocytes against glutamic acid decarboxylase and insulin in type 1 diabetes mellitus," Diabetes Research and Clinical Practice, vol. 51, no. 3, pp. 173-179, 2001. 


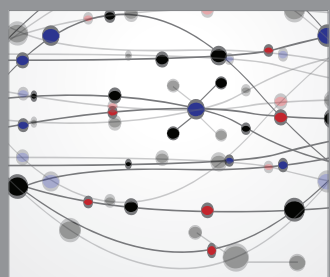

The Scientific World Journal
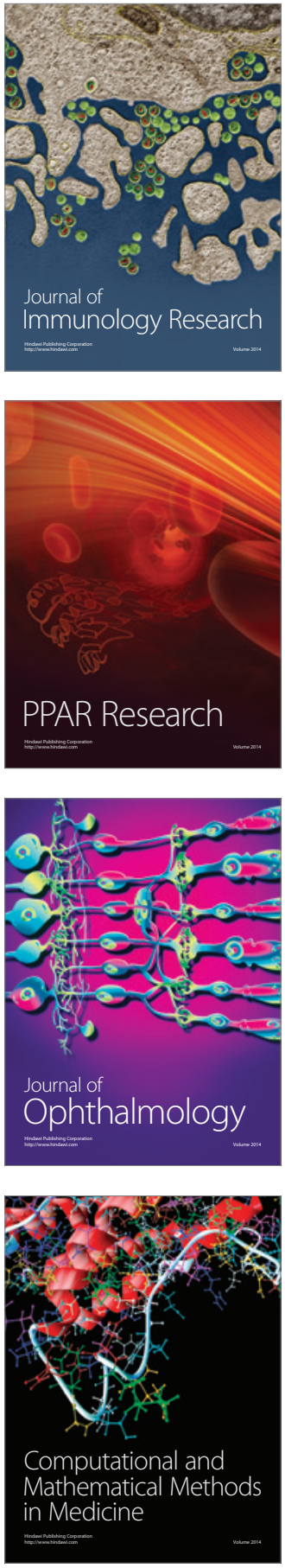

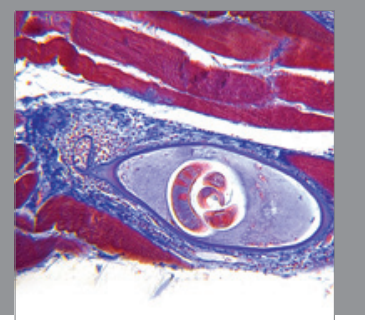

Gastroenterology

Research and Practice
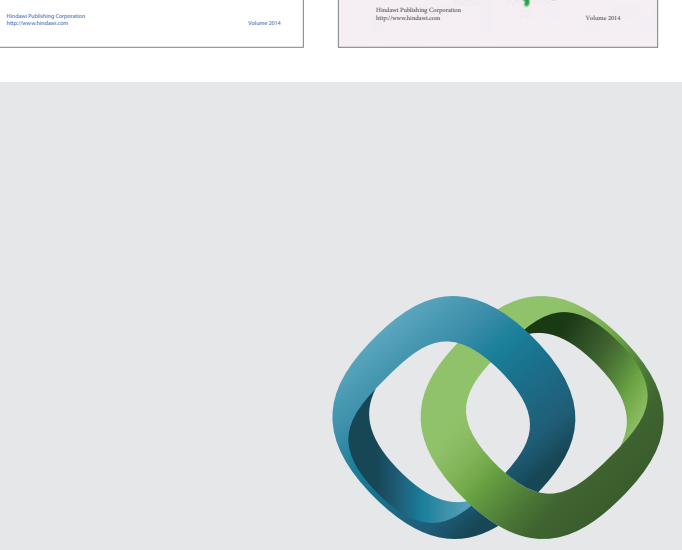

\section{Hindawi}

Submit your manuscripts at

http://www.hindawi.com
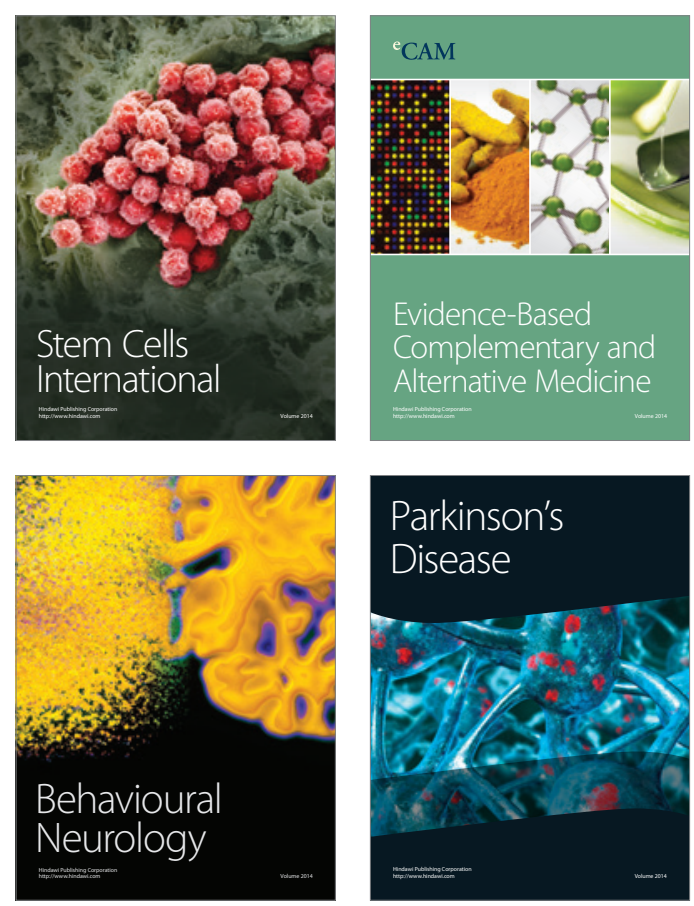

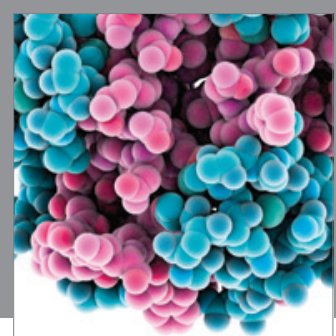

Journal of
Diabetes Research

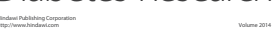

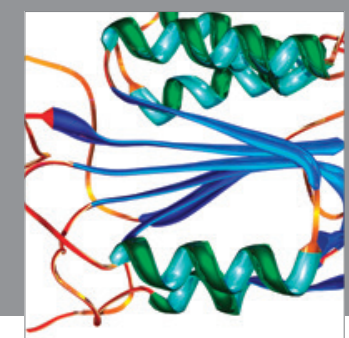

Disease Markers
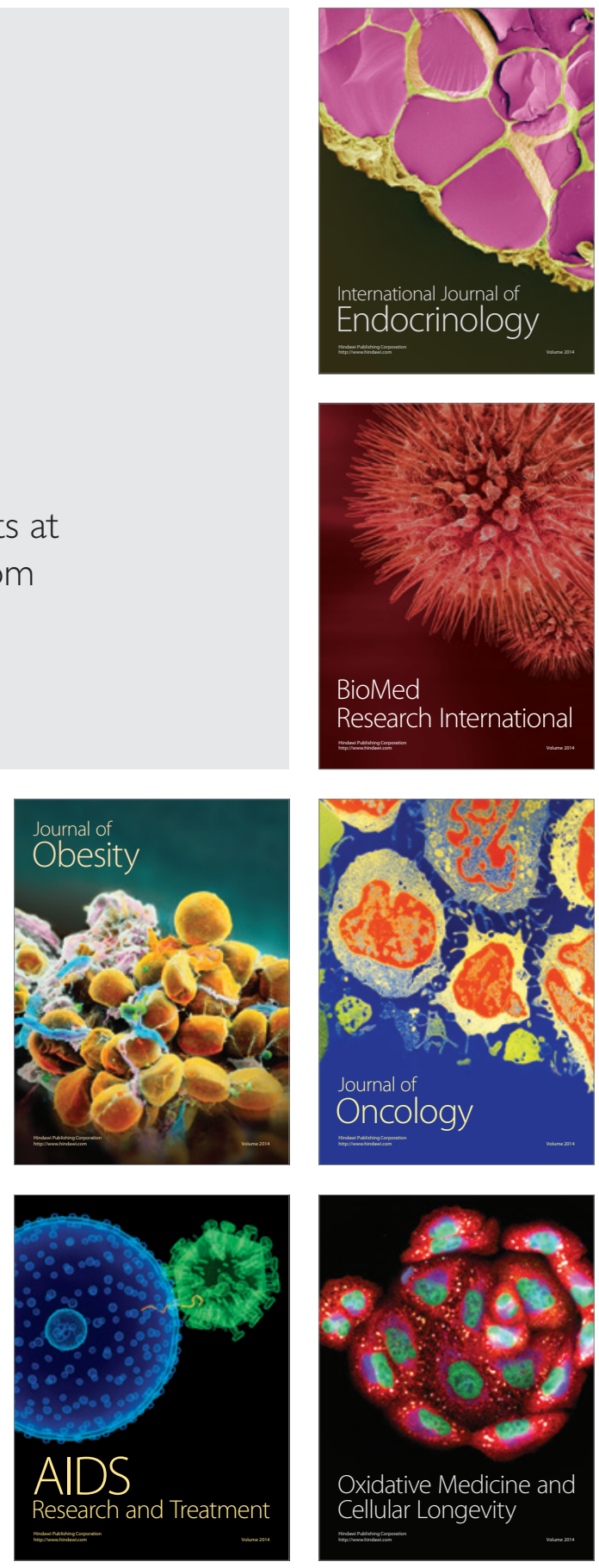